\title{
Kurumsal Halkla İlişkiler Aracı Olarak Bloglar: Türkiye'deki Bankaların Bloglarına Yönelik Bir İnceleme ${ }^{l}$
}

\author{
Blogs As A Tool Of Corporate Public Relations: An Analysis Of Banks Blogs In \\ Turkey
}

Selin BITIRIM OKMEYDAN*

$\ddot{O} Z$

Hedef kitleleri, sadık müşteriler haline getirecek stratejik iletişim süreçleri kurumsal halkla ilişkiler (Corporate Public Relations- CPR) olarak tanımlanmaktadır. Bilgi ve iletişim teknolojileri sonucunda hız kazanan küreselleşme karşısında kurumsal halkla ilişkiler, yeni uygulama alanları ile çeşitlenmektedir. Bu yeni uygulama alanları içerisinde en dinamik öge olan sosyal medya; işletmeleri, rakiplerinden öne çıkaracak ve farklılaştıracak iletişim araçlarının, kurumsal halkla ilişkiler çalışmalarına entegre edilmesini gerektirmektedir. Geleneksel medyadan sosyal medyaya doğru evrilen kurumsal halkla ilişkiler uygulamalarından biri de bloglardır.

Bu çalışma, kurumsal halkla ilişkiler uygulamalarının, sosyal medyadaki temel araçlarından biri olan blog kullanımını Türkiye'deki bankalar ekseninde incelemeyi amaçlamaktadır. Bu amaç doğrultusunda nitel araştırmaya dayanan çalışmada, uluslararası marka değerlendirme kuruluşu Brand Finance tarafindan her yıl açıklanan 'Banking (Bankacılık) 500 Raporu'nun 2019 yılı sonuçlarından yararlanılmıştır. Buna göre dünyanın en değerli ve en güçlü 500 banka markası içerisine giren dokuz Türk bankasından, bloğu olan ve aktifblog kullanımına sahip Garanti BBVA, Türkiye IŞ Bankası ve TEB (Türk Ekonomi Bankası) olmak üzere üç banka amaçlı örneklem yöntemine göre seçilmiştir. Bu üç bankanın, kurumsal halkla ilişkiler amaçlı blog kullanım örüntüleri betimsel içerik analizine tabi tutulmuştur. Gerçekleştirilen betimsel içerik analizinde üç bankanın bloğunda, öne çıkan paylaşım temaları belirlenip değerlendirilmiştir. Incelenen bloglarda elde edilen bulgulara göre üç bankanın kurumsal halkla ilişkiler amaçlı blog kullanımında en çok 'Sosyal Yaşam' kategorisine ait içeriklere yer verdiği görülmüşı̈̈r. Araştırma sonucuna göre 'Gezi/Seyahat' kategorisinin ise en az sayıda paylaşım aldı ̆̆ tespit edilmiştir.

ANAHTAR KELIMELER

Kurumsal Halkla İlişkiler, Sosyal Medya, Blog

\begin{abstract}
Strategic communication processes that will transform target audiences to loyal customers are defined as corporate public relations. Globalization, which is accelerating with information and communication technologies, diversify corporate public relations with new areas of application. Social media, the most dynamic element in these new areas of application, it requires the integration of communication tools that will distinguish and differentiate enterprises from their competitors in corporate public relations activities. One of the corporate public relations practices evolving from traditional media to social media is blogs.
\end{abstract}

This study aims to examine of blog usage of banks in Turkey in the scope of the corporate public relations activities. By this purpose a qualitative research has conducted and this research benefited from the results of 'Banking 500 Report' published by Brand Finance in 2019. As stated in the report, nine Turkish banks have entered the list of the most valuable and powerful 500 banks. Three of them which actively using their blogs such as Garanti BBVA, Türkiye İs Bankasl ve TEB (Türk Ekonomi Bankasi) has selected via purposive sampling method. These banks were subjected to content analysis in terms of blog usage in corporate public relations. In the content analysis the prominent posted themes were identified in the blogs of the three banks. According to the results, the patterns of using these blogs as a means of corporate public relations has discovered. According to the findings obtained in the examined blogs, the most posted content category has been seen as 'Social Life'. It was determined that the category of 'Trip/Travel' has received as the least number of content.

\section{KEYWORDS}

Corporate Public Relations, Social Media, Blog

\begin{tabular}{|c|c|c|}
\hline & $\begin{array}{l}\text { Makale Geliş Tarihi / Submission Date } \\
\text { 05.02.2020 }\end{array}$ & $\begin{array}{c}\text { Makale Kabul Tarihi / Date of Acceptance } \\
\text { 04.06.2020 }\end{array}$ \\
\hline Attf & \multicolumn{2}{|c|}{$\begin{array}{l}\text { Bitirim Okmeydan, S. (2020). Kurumsal Halkla İlişkiler Aracı Olarak Bloglar: Türkiye'deki Bankaların Bloglarına } \\
\text { Yönelik Bir İnceleme. Selçuk Üniversitesi Sosyal Bilimler Meslek Yüksekokulu Dergisi, } 23 \text { (2), 443-459. }\end{array}$} \\
\hline
\end{tabular}

\footnotetext{
${ }^{1} \mathrm{Bu}$ çalışma 14-15 Aralık 2019 tarihleri arasında düzenlenen İKSAD 4. Uluslararası Sosyal Bilimler Kongresi’nde sunulmuş bildirinin gözden geçirilerek eklemeler yapılmış ve genişletilmiş halidir.

*Dr. Öğr. Üyesi, Ege Üniversitesi İletişim Fakültesi, selin.bitirim.okmeydan @ ege.edu.tr, ORCID: 0000-0002-7996-2178
} 


\section{GİRIŞ}

Bilişim teknolojilerinde yaşanan değişimler ve gelişmeler, toplumsal yaşamı bütünüyle etkilemiş; her geçen gün hayatımıza dahil olan yeni kavramlar ve uygulamalarla toplumsal süreçler köklü ve derin şekilde dönüşmüştür. Bu dönüşüm, Web 2.0 teknolojileri ile çok daha kolay ve görünür hale gelmiştir. Sosyal medya kavramını ortaya çıkaran Web 2.0 teknolojileri; üretilen bilginin ve içeriğin kolay ve hızlı şekilde dünya geneline yayılmasına, çift yönlü iletişime ve kullanıcılar arasında gelişen etkileşime izin veren bir yapıya sahiptir. Thomas'a (2011: 194) göre sosyal medya aracılığıyla kurumsal gelişmeler ile haberlerin hedef kitlelere ve paydaşlara ulaşması, dijital platformlarda görünürlügün artması sonucu kurumsal farkındalığın gelişmesi, kurum lehine dikkat çekici içeriklerin oluşturulup daha çok kişiye hitap edilmesi, çift yönlü iletişim ile sohbet ortamının ve güçlü ilişkilerin kurulması ve kurum ile hedef kitleleri arasında etkileşimin süreklilik kazanması, kurumsal imajın ve itibarın oluşturulup geliştirilmesi mümkündür. Sosyal medyanın kurumlar açısından taşıdığ kurumların sosyal medya araçlarına olan ilgisi de artmaya başlamıştır. Kurumlar açısından yönetmesi kolay, maliyeti düşük, etkisi yüksek ve etkileşime açık bir iletişim aracı olan bloglar, ilk ortaya çıktığı günden bu yana giderek popülerleşmiş, günümüzde de kurumların halkla ilişkiler uygulamalarının yönetildiği önemli dijital platformlar arasındaki yerini korumayı başarmıştır.

Bloglar, kurumsal halkla ilişkiler aracı olarak önemli işlevlere sahiptir. Kurumsal halkla ilişkilerden temel beklentiler arasında yer alan etkileşim ve ilişki kurmak, çift yönlü iletişime süreklilik kazandırarak diyalog oluşturmak, kuruma olumlu imaj ve itibar yaratıp sürdürmek, kurumu diğerlerinden farklılaştıracak iletişim stratejilerine hayat vermek, kurumun markalaşmasına ve bir marka değeri elde etmesine katkıda bulunmak gibi hedefler, sosyal medyada bloglar üzerinden sağlanabilmektedir. Bu yönden kurumlara samimi ve insani bir yapı kazandıran bloglar; kurum ile hedef kitleleri ve paydaşları bir araya getiren, kurum ile mevcut ve potansiyel müşterileri arasında diyalog kurarak gündem oluşturmayı ve yönetmeyi sağlayan, kamuoyunun en çok konuştuğu konulara farklı perspektiflerden çeşitli yorumlar getirilmesine olanak veren dinamik bir iletişim platformudur. Dolayısıyla bloglar, günümüzde artık küresel düzeye ulaşan rekabet ortamı içerisinde ayakta kalmak isteyen kamu sektörü ve özel sektörde faaliyet gösteren kurum ve kuruluşlar tarafından dikkate alınması gereken bir iletişim ortamıdır. Hizmet sektörü içerisinde yer alan bankalar da hedef kitleleri ve paydaşları ile karşılıklı güvene dayalı iletişim geliştirmek zorunda olan finansal kuruluşlardır. Ulusal ve dahası küresel rekabetle başa çıkmak isteyen tüm kuruluşlar gibi bankalar için de sosyal medya ortamlarından ve araçlarından yararlanmak artık bir zorunluluk halini almıştır. Bankaların kurumsal halkla ilişkiler aracı olarak kullandıkları en güçlü iletişim enstrümanlarından biri de bloglardır.

Bu noktadan hareketle çalışmanın hedefi Türkiye'deki bankaların kurumsal halkla ilişkiler ekseninde blog kullanma amaçlarını ve örüntülerini saptamaktır. Alanyazın taramasında ve bu konuda gerçekleştirilen araştırmalarda, bankaların bloglarını halkla ilişkiler ekseninde ele alan çalışma sayısının oldukça kısıtlı olduğu görülmüştür. Ulusal ve uluslararası alanyazın taramasında banka bloglarını kurumsal halkla ilişkiler odaklı inceleyen bir araştırmaya ise rastlanmamıştır. Bu nedenle çalışma, alanyazındaki mevcut boşluktan hareketle bankaların kurumsal halkla ilişkiler amacıyla blog kullanımına odaklanmış ve bu kapsamda blog kullanım örüntülerini ortaya çıkarmayı hedeflemiştir. $\mathrm{Bu}$ hedef doğrultusunda, uluslararası bağımsız marka değerlendirme kuruluşu olan Brand Finance tarafından 'Bankacılık 500 Raporu' adıyla her yıl yayımlanan dünyanın en değerli ve en güçlü banka markalarına ait 2019 verileri dikkate alınmıştır. Bu verilere göre 2019 yılında dünyanın en değerli ve güçlü 500 bankası arasında dokuz Türk Bankası yer almıştır. Ancak bu dokuz banka içerisinde bloğu olan ve bloğunu aktif kullanan üç banka saptanmış, bu bankalar; Garanti BBVA, Türkiye İş Bankası ve TEB (Türk Ekonomi Bankası) olarak sıralanmıştır. 5 Ekim-5 Aralık 2019 tarihleri arasında söz konusu üç bankanın kurumsal bloglarına içerik analizi uygulanmıştır. Bu süreçte belirli kavram grupları oluşturmak için kodlama cetveli hazırlanmıştır. Kodlama cetveline göre ortaya çıkan kategoriler sırasıyla; 'Sosyal Yaşam', 'Yararlı Bilgi', 'Teknoloji', 'Ekonomi', 'Etkinlik' ve 'Gezi/Seyahat' olarak belirlenmiştir. İçerik analizinden elde edilen sonuçlara göre bankaların kurumsal halkla ilişkiler amaçlı blog kullanma örüntüleri tartışılıp yorumlanmıştır. Bankaların kurumsal halkla ilişkiler eksenli blog kullanımını ortaya çıkarmaya odaklanan çalışma, alanyazında mevcut bir eksikliği gidermek amacıyla kaleme alınmıştır. Dolayısıyla bu çalışma, alanyazına özgün katkı sunması ve var olan boşluğu doldurması açısından önemli görülmektedir.

\section{Kurumsal Halkla İlişkiler (CPR) ve İşlevleri}

Günümüzde her sektörde faaliyet gösteren işletmelerin hedef kitleleriyle karşılıklı güvene, anlayışa ve iş birliğine dayalı sürdürülebilir iletişimi oluşturup geliştirmek, modern bir yönetim fonksiyonu olarak değerlendirilen halkla ilişkilerin temel varlık sebebidir. Bugün alanyazında yüzlerce halkla ilişkiler tanımı 
yapıldığı görülse de halen üzerinde anlaşmaya varılmış genel geçer bir halkla ilişkiler tanımlamasından söz etmek mümkün değildir. Cutlip vd.'nin, 1985 yılında yaptıkları çalışmada halkla ilişkilere yönelik 472 tanım olduğunu belirtmelerine rağmen; aradan geçen yıllardan sonra günümüzde 500'ün üzerinde tanım yapılması, bu alanın tanımlanmasında sorunların çoğalması anlamına gelmektedir (Yıldız, 2010: 25). Bu durumun en önemli nedenlerinden biri, halkla ilişkilerin disiplinlerarası bir alan olarak kuramsal ve uygulama odaklı birbirinden çok farklı çalışma dallarını kapsaması ve her disiplinin kendine özgü bakış açısı doğrultusunda tanım yapılmasıdır. Ancak yine de halkla ilişkilere yönelik yapılan her tanımın, belirli ortak özellikleri işaret etmesinden hareketle Guth ve Marsh (2003: 7); 'yönetim işlevi', 'çift yönlü iletişim', 'planlanmış faaliyet', 'araştırmaya dayalı sosyal bilimler' ve 'sosyal açıdan sorumlu davranış' ögelerinin, herhangi bir halkla ilişkiler tanımının temel bileşenlerini oluşturmasını önermişlerdir. Bu doğrultuda Dr. Rex Harlow’un, halkla ilişkiler tanımlarının her birini inceleyerek yüzlerce tanımı bir araya getirecek kapsayıcı bir içerikle ve IPRA (Uluslararası Halkla İlişkiler Derneği) tarafından 'iyi bir tanım' olarak nitelendirilen halkla ilişkiler tanımı şöyledir (Seitel, 2016: 5):

Halkla ilişkiler, bir kurumun çeşitli hedef kitleleri arasında karşıllklı iş birliği, anlayış, kabullenme ve iletişim bağlarını kurup sürdüren, birbirinden farklı sorunların yönetilmesini ve çözümünü içeren, üst yönetimin hedef kitlelerin ihtiyaç ve beklentileri doğrultusunda sürekli bilgilendirilmesine yardımcı olan, üst yönetimi hedef kitlelerine duyarlı hale getirerek yönetimin toplumsal sorumluluğunu vurgulayan, yönetimin değişikliklerden yarar görecek şekilde çevresel değişikliklere ayak uydurmasına yardımcı olan, kurumun olası krizleri öngörmesini sağlayacak erken bir uyarı sistemi işlevi ile hareket eden ve hedef kitlelerine karşı açık, şeffaf, güvenilir ve etik iletişim yöntemlerini ve araştırma tekniklerini kullanan kendine has özelliklere sahip çağdaş bir yönetim görevidir.

Bu tanım ışığı altında halkla ilişkilerin, hedef kitleleri ile sürdürülebilir bir iletişim sürecine vurgu yaptığını söylemek mümkündür. Hedef kitlelerin bu şekilde karşılıklı ve çift yönlü iletişim sürecine dahil olması, halkla ilişkilerin iki temel işlevi olan hedef kitleleri 'tanıma' ve onlara kendini doğru bir şekilde 'tanıtma' firsatını beraberinde getirmektedir (Mert, 2018: 725). Halkla ilişkiler, hedef kitlelerini doğru şekilde analiz edebilmek için öncelikle onları tanımak zorundadır. Tanıma aşamasından elde edilen veriler sonucunda hedef kitlelerin isteklerini ve beklentilerini dikkate alan stratejik iletişim çabalarının uygulanması ise tanıtma aşamasını ifade etmektedir. "İşletmeler, tanıtım çalışmaları ile temasa geçtikleri iç ve dış çevrelerde güven, destek, anlayış ve sempati kazanıp bunu sürdürebilmeyi amaçlamaktadır. Bu nedenle tanıtım, işletmelerin meşruiyeti ve temel faaliyetleri ile ilgili olarak hedef kitlelerde herhangi bir kuşkuya yer vermeyecek şekilde bilgilerin aktarılması ve sürekli paylaşılması anlamına gelmektedir" (Okmeydan ve Saran, 2018: 36). Günümüz dünyasında halkla ilişkilerden beklenen öncelikli görevler arasında hedef kitleleri ile etkili iletişim geliştirmek, sürdürülebilir ilişkiler inşa etmek ve bunun sonucunda işletmelere olumlu imaj ve itibar kazandırmak yer almaktadır. Halkla ilişkilerin öncelikli görevleri arasında tanımlanan bu unsurlar, halkla ilişkilerin kurumsal boyutuna işaret etmektedir.

Dolayısıyla halkla ilişkilerin iki temel unsuru olan tanıma ve tanıtma işlevi, halkla ilişkilerin kurumsal odaklı uygulamalarını ön plana çıkarmakta ve alanyazında kurumsal halkla ilişkiler (CPR) adı altında incelenmektedir. Kurumların halkla ilişkiler uygulamalarında tanıma ve tanıtma faaliyetlerinin kuramsal bilgisi ve çeşitli uygulamaları kurumsal halkla ilişkiler tarafından yönetilmektedir (Bilgin, 2010: 133). Kurumsal halkla ilişkiler; imaj ve itibar yönetimi, etkinlik yönetimi, kurumsal sosyal sorumluluk ve kurumsal reklam gibi farklı alanlarda uygulanmakta ve kurum ile hedef kitleler arasında etkili bir tanıma ve tanıtma çabasını vurgulamaktadır (Kartal ve Algül, 2019: 59). Harris (1993: 14) kurumsal halkla ilişkilere, hedef kitlelerden gelecek bilgiler için üst yönetime danışmanlık yapmak (tanıma) ve üst yönetimin kurumsal hedeflerinin hedef kitleler tarafindan anlaşılmasını sağlamak için (tanıtma) ihtiyaç duyulduğunu ileri sürmektedir. Halkla ilişkiler uygulamaları, pazarlama amaçlı (MPR) ve kurumsal amaçlı (CPR) halkla ilişkiler olmak üzere iki farklı eksende ele alınmaktadır. Halkla ilişkiler uygulamalarının, satışları doğrudan artırmayı ve sonucunda kâr elde etmeyi içeren pazarlama odaklı girişimlerinden ziyade kurumsal halkla ilişkilerde, işletmelerin imajını ve itibarını güçlendirerek hedef kitlelerde müşteri bağlılığı yaratacak uzun dönemli ilişkileri sürdürmek ve yönetmek esastır. Bozkurt'a (2007: 122) göre pazarlama yönlü halkla ilişkiler tamamen ürün, satış ve pazarlama ile ilgilenirken kurumsal halkla ilişkiler ise kurumsal ilişkiler ve imaj-itibar oluşumu ile ilgilenmektedir.

Hedef kitlelerin ve genel olarak toplumun güvenini, sevgisini ve sempatisini kazanmak amaciyla yürütülen halkla ilişkiler çalışmalarını içeren bir kavram olan kurumsal halkla ilişkiler; şirketin ve ürünün tanıtımını doğrudan desteklemek, imajı şekillendirmek, itibar yaratmak, güvenilir bilgi iletmek ve yararlı sosyal 
faaliyetleri desteklemek amaciyla işletmenin mevcut ve potansiyel müşterileri ile diğer izleyici grupları arasındaki etkileşimi içerir. Temel misyonu; müşterilerin işletmeye yönelik farkındalığını artırmak, işletme ve müşteriler arasında uzun dönemli ilişkiler kurup iletişimi kolaylaştırmak ve sürdürmek yoluyla dolaylı şekilde kârlılığın büyümesini sağlamaktır (Olędzki, 2017: 1). Wilcox ve diğg. (1998: 10-11), kurumsal halkla ilişkilerin temel faaliyet alanlarını şu şekilde tanımlamaktadır:

Kurumsal halkla ilişkiler; rakipler, medya, yatırımcılar, hükümet ve topluluklar gibi müşteri olmayan kamuoyu ile olduğu kadar çalışanlar, paydaşlar ve ortakların ilişkileriyle de ilgilidir. Bu nedenle kurumsal halkla ilişkiler; mevcut ve potansiyel müşteriler ile rakiplere yönelik çeşitli araştırmaları, medya ilişkilerini, tanıtım çalışmalarını, çeşitli danışmanlıkları, iç ve dış çevrelerle ilişkileri, topluluk ilişkilerini, kamu ilişkilerini ve devlet kurumlarıyla etkileşimi, endüstriyel ilişkileri, aracılar ve finans kuruluşlarıyla bağlantıları, sivil toplum, dernek, vakıf ve sendikalarla bağlantıları, kanaat önderleri ile kişisel bağlantıları, konu, sorun ve kriz yönetimini de içeren geniş bir uygulama alanına işaret etmektedir.

$\mathrm{Bu}$ doğrultuda işletmeler kurumsal halkla ilişkilerden; marka bilinirliği oluşturmak, marka imajını ve itibarını geliştirmek, müşteri sadakatini artırmak için çevre ile etkili ilişkiler kurmak, işletmenin pazardaki rekabet gücünü güçlendirmek, iç ve dış çevrelerde işletmeye olumlu bir atmosfer yaratarak işletmenin gelişmesini sağlamak amacıyla yararlanmaktadır (Gawroński ve Jakubowski, 2018: 10). Kurumsal halkla ilişkiler uygulamaları, geleneksel medyada olduğu gibi sosyal medyada da devam etmekte ve bilgi iletişim teknolojilerinin desteğiyle gelişen farklı araçlarla çeşitlenmektedir. Geleneksel medyadan sosyal medyaya taşınan kurumsal halkla ilişkiler uygulamalarının araçlarından biri de bloglardır ve bloglar, kurumsal halkla ilişkiler açısından çeşitli fırsatlar taşımaktadır.

\section{Sosyal Medyada Kurumsal Halkla İlişkilerin Vitrini: Bloglar}

Sosyal medya, Web 2.0 tabanlı yeni nesil internet teknolojilerini ifade eden ve genel anlamıla iletişim sürecinde etkileşim, katılım, içerik üretme, hız ve kolaylık gibi unsurlara vurgu yapan genel bir isimdir. "Web 2.0 'ın en önemli özelliği, bilginin iş birliği içinde üretilip çevrim içi olarak paylaşılmasına izin vermesidir. Web 2.0, medyayı sosyal hale getirmekte ve interaktif etkileşim ortamı sağlamaktadır" (Koçyiğit, 2017: 91). Web 2.0 temelinde gelişen ve yeni medya ya da sosyal medya olarak tanımlanan yeni iletişim teknolojileri, bireysel kullanıcıların ve kurumların bu dijital ortamları kullanmasını olanaklı kılmaktadır (Zyl, 2009: 908). Sosyal medya ortamları; hız, esneklik, işlevsellik, kolay ve zengin içerik üretimi, karşılıklı iletişim ve etkileşim gibi iletişim sürecine doğrudan etki eden unsurlara dayanması nedeniyle özgürlük, dürüstlük ve şeffaflık gibi değerleri de pekiştirmektedir (Koçak, 2017: 147). Bayraktutan ve diğ. (2012), Web 2.0 teknolojileri ile internet uygulamalarının katılımcı ve etkileşime açık hale geldiğini, böylece içerik oluşturup bu içerikleri hızlı şekilde yaymak kolaylaşırken üretilen içeriklerin yayılmasında kullanılan en etkili araçlar arasında sosyal paylaşım ağları ile blogların ön planda yer aldığını belirtmiştir. Wright'a (2005: 19) göre sosyal medyanın çift yönlü ve geri bildirime olanak veren yapısı bloglarda da aktif olarak karşımıza çıkmaktadır. Geleneksel medyada hâkim olan tek yönlü iletişimin aksine sosyal medyada ve özellikle bloglarda karş1lıklı ve çift yönlü iletişim süreci söz konusudur. Bloglar, hedef kitleleri yalnızca 'bilginin tüketicisi' olmaktan çıkararak onların, bu bilgiyi düşünüp analiz etmelerine ve kendi aralarında paylaşarak yeniden üretmelerine olanak vermektedir (Jarvis, 2011: 176). Bloglarda ortaya çıkan karş1ıklı ve çift yönlü iletişim süreci, kurumların hedef kitleleri ile doğru etkileşimler yaratmasına ve sürdürülebilir ilişkiler inşa etmesine katkıda bulunmaktadır.

Web (internet tarayıcıları ile ulaşılan iletişim ortamı) ve log (kayıt anlamında) İngilizce kelimelerinin bir araya gelmesiyle ortaya çıkan 'Weblog' kelimesinin kısaltılmışı olan blog (Dilmen, 2007: 116) terimi; 'internet günlügü', 'elektronik günlük (e-günlük)' veya 'ağ günlüğ̈̈' olarak ifade edilmektedir. Kullanımında teknik bilgi ya da donanım gerektirmediği için yönetilmesi kolay olan zengin içerikli ve işlevsel web alanlarını tanımlayan bloglar, kişisel ve kurumsal kullanıma olanak veren tasarımı sayesinde yazılı ve görsel üretilen içeriklerin tüm dünyaya eş zamanlı ulaşmasını sağlamaktadır (Alikılıç ve Onat, 2007: 903-904). Sıkça güncellenebilen gönderilerin en yeniden en eskiye doğru ters kronolojik sıralamayla kayıt altına alındığı, çoklu yazarlardan oluşan kullanıcıların yorum yaparak duygu ve düşüncelerini paylaşabildiği bloglar, kurumların paydaşları ile çift yönlü ve sürekli iletişim kurabilmek için kurumsal halkla ilişkiler aracı olarak kullanılan dijital içerik yönetim sistemidir (Gunelius, 2011: 4). Kullanım kolaylığı ve kurumlara sağladığı yararlar açısından bloglar, günümüzde kullanılmaya devam eden en popüler halkla ilişkiler araçlarından biridir. Sevinç'e (2012: 68) göre bloglar, kaliteli içeriğin üretileceği merkez ve ana üstür; herhangi bir marka veya kurum için merkezinde blog olmayan sosyal medya stratejisinin günümüzde başarılı olması olanaksızdır. Holtz ve Demopoulos (2006: 21), blogların kurumlara sağladığı faydaları şu şekilde özetlemektedir: 
Kurum ve hedef kitleler arasındaki iyi niyeti ve sempatiyi geliştirerek kurumsal markaları güçlendirmektedir. Ulaşılabilir ve maliyeti düşük araştırma kaynağı olarak rakip analizi için kurumlara rekabet firsatı sağlamaktadır. Kurumların karşı karşıya kalabileceği krizleri ortaya çıkmadan önlemeye, krizlerin önlenemediği durumlarda ise krizi doğru şekilde yönetebilmeye olanak vermektedir. Ağızdan ağıza pazarlama/iletişim ile daha çok kişiye ulaşılmasını sağlayarak mevcut ve potansiyel hedef kitleleri genişletmekte ve yeni müşteriler elde edilmesine yardımcı olmaktadır (Holtz ve Demopoulos, 2006: 21). Bunların yanı sira bloglar, kurumsal halkla ilişkilerin işlevlerinin sosyal medya ortamında da devam etmesine destek vermektedir.

Karaçor'a (2009: 93) göre blogların; araştırma ve bilgilen(dir)me, çevreyi tarama, hedef kitleleri tanıma, konu, sorun ve kriz yönetimi, kamuoyuna doğrudan ulaşma ve çift yönlü iletişim, kurum ve hedef kitleler arasında etkileşim, etkili ağızdan ağıza pazarlama gibi halkla ilişkiler açısından güçlü yönleri bulunmaktadır. Bazı noktalarda iç içe geçmekle birlikte blog türlerini beş grup altında toplamak mümkündür (Kahraman, 2013: 30-32):

Kişisel Bloglar: Duygu ve düşüncelerin anlatılarak hayat akışının paylaşıldığı, bir bakıma kişisel günlüklerdir.

Temasal Bloglar: Moda, yemek, dekorasyon, kitap, sanat, fotoğrafçıllk, spor, reklam pazarlama, siyaset, alışveriş gibi çok çeşitli konularda blog tutulabilir.

Portföy Bloglart: Her meslek için iş portföyünü bloglarda tutmak mümkündür. Böylelikle profesyonel hayat internete taşınır ve potansiyel işverenlere veya müşterilere ulaşılabilir.

Kurumsal Bloglar: Şirketlerin, tercihen çalışanları veya sosyal medya içerik sağlayıcıları tarafından tutulan bloglardır. Yeni çıkan ürünlerin veya hizmetlerin tanıtımı, düzenlenen etkinlikler, kazanılan ödüller, kurumsal bilgiler ve gündemle ilgili paylaşımlar yapılabilir.

Topluluk Blogları: Bir kişi değil de belli bir grubun yazdığı yazılardan oluşan bloglardır ve yukarıdaki tüm kategorileri içerisinde barındırabilir.

Wright ve Hinson (2008: 4), özellikle kurumsal blogların, halkla ilişkiler ve kurumsal iletişim açısından olağanüstü potansiyel etkiye sahip olduğunu belirterek sosyal medyada halkla ilişkilerin odak noktası olan kurumsal blogların; markalar, ürün ya da hizmetler ile ilgilenen kişilere ulaşmak, onlarla iletişime geçip etkileşim kurmak için en iyi ortamlar arasında yer aldığına işaret etmektedir. Bağlantı (link), belge, fotoğraf ve video eklenebilen bloglardan niş pazarları geliştirmenin yanı sıra uzmanlık ve belge paylaşımı, bilgilerin arşiv niteliğinde toplanması, yeni iş birliklerinin keşfedilmesi amacıyla da halkla ilişkiler aracı olarak yararlanılmaktadır (Adler ve Sillars, 2011: 85; Pradas vd., 2017: 221). Kurumsal bloglar sayesinde hedef kitleler kuruma veya kurumsal markaya daha çok maruz kalmaktadır. Böylelikle kurumun görünürlüğünü artmakta, imajı ve itibarı da olumlu etkilenmektedir. İyi bir marka imajı ve itibarına sahip olan kurumların marka değeri de artmaktadır. Kurumsal bloglar aracılığıyla kurumlar, müşteri ilişkileri yönetimini sosyal medyaya taşıyabilmekte ve sosyal müşteri ilişkileri yönetiminde de daha etkili ve başarılı sonuçlar elde etme potansiyeline sahip olmaktadır. Çetintaş'a (2014: 95) göre kurumsal bloglar, kurumları insanlaştırarak onlara ayırt edici bir kimlik kazandırmakta ve kurumların müşterileri ile güçlü ilişkiler kurmasını sağlamaktadır. Bu nedenle günümüzde kamu veya özel sektörde faaliyet gösteren tüm kuruluşlar gibi bankalar da hedef kitleleri ve paydaşları ile sürdürülebilir iletişim kurmak ve güveni perçinlemek için halkla ilişkiler aracı olarak kurumsal bloglardan yararlanmaktadır.

Bankalar, hizmet sektörü içinde yer alan finansal aracılardır ve bankacılık sektörü, halkla ilişkiler uygulamalarının en yoğun kullanıldığı iş kolları arasında yer almaktadır. Teknolojik yenilikleri tüm dünya ile eş zamanlı uygulamaya sokan bankalar, değişime öncülük etmektedir. Bankacılıkta halkla ilişkiler çalışmalarının önemi, insanların bu kurumları itibarlı algılamalarını ve bu kurumlara güven duymalarını sağlamaktır (Özdemir, 2012: 5). Dolayısıyla bankaların geleneksel iletişim ortamlarında yürüttükleri çalışmalarına ek olarak sosyal medya ortamlarındaki faaliyetleri de önem kazanmaktadır. Bu nedenle bankaların sosyal medya mecralarını her geçen gün daha aktif kullandıklarını ve hem potansiyel hem de mevcut müşserileri ile etkileşim kuracak yeni ve alternatif araçlara yöneldiklerini söylemek mümkündür. Kurumsal halkla ilişkilerin en önemli bileşenleri arasında yer alan müşteri ilişkileri yönetimi, diyalog, etkileşim ve çift yönlü iletişim, imaj ve itibar yönetimi, kurumsal marka gibi süreçler, günümüzde bankaların kurumsal blogları üzerinden işlemektedir.

\section{Kurumsal Halkla İlişkiler ve Blog Kullanımına İlişkin Araştırma Alanyazını}

Kurumsal halkla ilişkilerin sosyal medya ile bağlantısı incelenirken ulusal ve uluslararası alanyazında blogların halkla ilişkiler amaçlı kullanımına ilişkin çok sayıda araştırma yapıldığg görülmüştür. Barros (2014), 
sosyal medya ortamı olan blogların kurumlara meşruiyet kazandıran bir araç olarak kullanıldığına dikkat çektiği çalışmasında, kurumsal blogların söylem alanları oluşturup anlatımları meşrulaştırdığını ve hedef kitlelerle aktif bir etkileşim yaratma potansiyeline sahip olduğunu dile getirmiştir. Cho ve Huh (2010), ABD'deki büyük şirketlerin çeşitli müşterilerle ilişki kurmak ve sürdürmek için kurumsal blogları nasıl kullandıklarını inceledikleri çalışmada, ABD'de giderek artan sayıda büyük şirketin, blogları kurumsal bir iletişim aracı olarak benimsediğini ve kurumsal blogların ilişki kurup sürdürme eğilimine odaklanması gerektiğini belirtmişlerdir. Dennis (2016), kurumsal blogları sınıflandırmaya yönelik gerçekleştirdiği çalışma sonucunda Fortune 500 şirketleri tarafından işletilen blogların görünürlüğü artırdığı ve bu nedenle şirketlerin bloglardan kurumsal iletişim aracı olarak daha fazla yararlandıkları sonucunu elde etmiştir. Hsu ve Lin (2008), kurumsal blogları teknoloji kabulü, bilgi paylaşımı ve sosyal etki açısından değerlendirdikleri çalışmada, blogların teknoloji kabulü ve bilgi paylaşımı açısından hızlı gelişim gösterdiğini, bloglarda topluluk kimliği önemli olduğu için sosyal etkinin ortaya çıkmasının bu koşula bağlı olduğunu belirtmişlerdir. Kılıç (2011), Fortune 500'de yer alan kurumsal blog sahibi şirketlerin, blog sahibi olmayanlara göre gelir ve kâr oranlarını araştırdığ 1 çalışmasında iki grup arasında istatistiksel olarak ortaya çıkan anlamlı farklılıklara dikkat çekmiş ve kurumsal blogların halkla ilişkiler işlevlerini yerine getirmedeki başarısını vurgulamıştır. Luo vd. (2018), işle ilgili olmayan sosyal medya kullanımının şirketlere yarar getirip getirmediği üzerine gerçekleştirdikleri çalışmada, kurumsal bloglarda işle ilgili olmayan makalelerin yayımlanmasıyla çalışanların duygusal bağl1lı̆̆ının artırılabileceği sonucuna ulaşmışlardır.

Mucan ve Özeltürkay (2014) tarafından Türk bankalarının sosyal medyayı rekabet avantajı açısından nasıl kullandığına yönelik gerçekleştirilen çalışmada, Türkiye'deki bankaların rekabet avantajı yaratmada sosyal medyadan yeterince yararlanamadığı bulguları ortaya çıkmıştır. Bankalar açısından en çok tercih edilen sosyal ağların Facebook, Twitter ve LinkedIn olduğu, blogların ise bankalar tarafından etkin kullanılmadığı sonucuna dikkat çekmiştir. Özel ve Sert (2014), dijital halkla ilişkiler aracı olarak kullanılan kurumsal blogların analiz edilmesine dayanan çalışmada, Türkiye'nin En Büyük 500 özel şirketinin blog kullanımına odaklanmış ve kurumsal blog yapılandırılması konusunda önemli eksikliklere işaret ederek Türkiye'deki kurumsal blogların, blog kalite indeksi değerinin düşük olduğu sonucuna ulaşmışlardır. Parusheva (2019), Bulgaristan'ın en çok müşteriye sahip ilk 10 bankasındaki sosyal medya araçlarının çeşitli türlerini sosyal medya bankacılığı açısından değerlendirdiği çalışmasında, sosyal medyanın bütünüyle müşteri ilişkilerini geliştirme, müşterilerle etkileşim kurma, topluluk ilişkilerini yönetme gibi kurumsal halkla ilişkiler açısından önem taşıdığı sonucunu paylaşmıştır. Pitt vd. (2011), küresel çapta 332 blog kullanıcısına yönelik geliştirdikleri anket ile kurumsal blogların şirketler tarafından kullanılma kararını inceledikleri çalışmada, profesyonel halkla ilişkiler sektörünün, blogları da içeren iletişim kaynaklarından en iyi şekilde yararlanma ve blogların bilgi yönetim aracı olarak tam anlamıyla potansiyellerini geliştirme alanında öncü olması gerektiğine işaret etmişlerdir. Ramadanty ve Martinus (2018), Endonezya'daki halkla ilişkiler etkinliklerinde blog kullanıcıların rolüne odaklandıkları çalışmada, kurumsal blog yazarlarının halkla ilişkiler faaliyetlerine katılımının ürün incelemesine ve etkinlik duyurumuna fayda sağladığı için yararlı bir ilişki ve karşılıklı bir etkileşim oluşturduğunu belirtmişlerdir. Xifra ve Huertas (2008), kurumsal blogların etkileşimi ne yönde geliştirdiğini saptamak amacıyla hazırladıkları çalışmada, halkla ilişkiler odaklı 67 bloğun yapısını incelemişler ve genel etkileşimin zayıf kaldığı bulgularına ulaşmışlardır.

Bu çalışmanın amacı, Türkiye'deki bankaların bloglardan kurumsal halkla ilişkiler aracı olarak nasıl yararlandığını ortaya çıkarmaktır. Araştırma, blog kullanımının bankalar açısından nasıl işlediğini ve bankaların, bloglardan kurumsal halkla ilişkiler aracı olarak bilinçli bir şekilde yararlanıp yararlanmadığını saptamak açısından önemli taşımaktadır. Araştırma alanyazınında da görülebileceği üzere şimdiye kadar sosyal medya araçları ve halkla ilişkiler üzerine çok sayıda çalışma yapıldığı izlense de bankalarda blogların halkla ilişkiler amacıyla nasıl kullanıldığına odaklanan özgül (spesifik) araştırma sayısı yok denecek kadar azdır. Bankaların blog kullanımını kurumsal halkla ilişkiler odağından ele alan ulusal ya da uluslararası ölçekte bir çalışma ise daha önce hiç gerçekleştirilmemiştir. Bu nedenle çalışma ilgili alanda var olan boşluğu gidermek yönünden önemli ve alanyazına özgün katkı sağlamak açısından değerli görülmektedir. Buradan hareketle 2019 yılında yayımlanan Banking (Bankacılık) 500 Raporu içerisindeki Türk Bankalarının, halkla ilişkiler amacıyla kurumsal bloglardan nasıl yararlandığı, temel araştırma sorusu olarak belirlenmiştir. Türk Bankalarının kurumsal blogları hangi amaçlarla kullandığı ve kurumsal bloglarda en sık kullanılan paylaşımların hangi içeriklerden oluştuğu ise bu çalışmada yanıt aranan ikincil sorulardır. 


\section{Araştırmanın Yöntemi}

Araştırmanın örnekleminde uluslararası bağımsız marka değerlendirme kuruluşu olan Brand Finance'ın 'Banking 500-2019 Raporu'• içerisinde yer alan dokuz Türk Bankası yer almaktadır. İlgili rapora göre Türkiye'nin en değerli bankaları arasında sırasıyla; Ziraat Bankası, Garanti Bankası (Garanti BBVA), Türkiye İş Bankası, Akbank, Yapı Kredi, Türkiye Halk Bankası (Halkbank), VakıfBank, DenizBank ve TEB (Türk Ekonomi Bankası) olmak üzere dokuz banka listede yerini almıştır. Ancak bu bankalar içerisinde sadece Garanti BBVA, Türkiye İş Bankası ve Türk Ekonomi Bankası'nın (TEB) kurumsal bloğunu aktif şekilde kullandığı görülmüştür. Geri kalan diğer bankaların bazılarının kurumsal bloğunun olmadığı ve bazılarının ise kurumsal bloğu olmasına rağmen aktif kullanılmadığı tespit edilmiştir. Ayrıca 'Akbank Sanat' gibi iş süreçleri dışında kullanılan ve bankanın kendi sponsorluğunda gelişen çeşitli kültürel ve sanatsal aktiviteleri içeren bloglar da kapsam dışı bırakılmıştır. Neuman'a (2012: 320) göre nitel araştırmalarda çalışma grubu, konunun içeriğine göre belirlenir ve araştırmacı, çalışma grubunu seçerken belirli ölçütleri göz önüne alır. Bu nedenle araştırmada, amaçlı örneklemden yararlanılmıştır. Amaçlı örneklemenin temeli, araştırmaya dahil edilen değişkenler hakkında derinlemesine ve zengin bilgiler elde etmektir (Özdemir, 2010: 327). Amaçlı örnekleme göre kurumsal bloglarını en aktif kullanan üç banka olduğu tespit edilmiş ve Garanti BBVA, Türkiye İş Bankası ve TEB (Türk Ekonomi Bankası) olmak üzere incelemeye alınan üç banka, 5 Ekim-5 Aralık 2019 arasındaki iki aylık süreç kapsamında araştırmaya dahil edilmiştir.

Nitel araştırmaya dayalı bu çalışmada, veri toplama tekniği olarak doküman analizinden yararlanılmıştır. Doküman analizi sürecinde araştırma kapsamındaki veriler, bankaların kurumsal bloglarında yer alan paylaşımlardan elde edilmiştir. Doküman analizi, araştırılan konularla ilgili detaylı bilgi içeren çeşitli materyallerin incelenmesini içermektedir. Yıldırım ve Şimşek’e (2013: 217) göre nitel araştırmanın veri toplama sürecinde gözlem ve görüşmenin mümkün olmadığ 1 durumlarda ya da araştırmanın güvenilirliğini artırmak için araştırılan konu ile ilgili yazılı ve görsel materyaller de araştırmaya dahil edilir. Bu nedenle doküman analizi tek başına bağımsız bir araştırma yöntemi olabileceği gibi ek bilgi kaynağı olarak da kullanılabilir. Araştırma sorununa yönelik yazılı ve görsel dokümanların incelenmesi, daha zengin ve detaylı bilgiler ve çıkarımlar sağlanması açısından oldukça önemlidir. Ayrıca dokümanların kayıtlar, fotoğraflar ve metinler gibi materyalleri içermesinden dolayı araştırmacı tarafından yorumlanması gerekmektedir (Baş ve Akturan, 2013: 119). Bu araştırmadaki doküman incelemesinde seçilen üç bankanın kurumsal bloglarında paylaşılan içeriklere ulaşılmış, bu içerikler ilk 10 paylaşım ile sınırlandırılarak toplam 30 paylaşıma ulaşılmıştır. Suziki ve diğ. (2007: 318), dokümanların elektronik formatta da elde edilebileceğine dikkat çekerek elektronik verinin; yazılı ve görsel dokümanların yanı sıra web sayfaları ve bloglar gibi çeşitli ve zengin türde veriyi kapsadığını belirtmişlerdir. Bu noktada basılı veya elektronik formattaki dokümanların içeriğinin yorumlanması ve sözel olarak ifade edilmesi önemli bir husus olarak karşımıza çıkmaktadır. Giarelli ve Tulman (2003: 951), doküman analizinde araştırmacıların, yorumlayıcı içerik analizi yapmak durumunda olduğunu belirtmektedirler. Yorumlayıcı içerik analizi, dokümandaki temaların, konuların ve olguların belirlenip tanımlanmasını içermektedir. İncelenen üç bankanın bloğunda, en son paylaşılan 10 içerik olmak üzere toplam 30 içerik, blog kullanım amaçları ve kurumsal halkla ilişkiler açısından yorumlanıp açıklanmaya çalışılmıştır.

İletişim çalışmalarında süreç içerisinde yer alan iletilerin analizi için sıklıkla kullanılan önemli yöntemlerden biri içerik analizidir. Analiz edilecek ileti, metin içeriklerinden oluşmaktadır ve metin ise her türlü yazılı, görsel ve sözlü ögelerdir (Aziz, 2015: 131). İlk kez 1952 y1lında Berelson'un 'İletişim Araştırmalarında İçerik Çözümlemesi' (Content Analysis in Communication Research) isimli çalışmasıyla iletişim çalışmalarında modern bir yöntem olarak kabul gören (Atabek ve Atabek, 2007: 2) içerik analizi, ileti içeriğini çözümlemenin sistematik ve bilimsel bir yöntemidir. Anket, gözlem ya da görüşme yöntemi gibi araştırmacı, içerik analizinden yararlanarak herhangi bir zaman veya yerde üretilmiş iletişim iletilerini çözümler (Severin ve Tankard, 1994: 41). İçerik analizi, bir gözlem yönteminden ziyade bir çözümleme yöntemidir. Objektif, sistematik ve sayısal çözümlemeye dayalı bu yöntem ile yazılı metinler kolaylıkla anlaşılabilmekte, bu sayede araştırmacının konuya yaklaşımı çözümlenerek araştırmanın içeriği bilimsel bir zemine inşa edilebilmektedir (Yengin, 2017: 77-78). Çalışma kapsamında doküman analizi yoluyla elde edilen veriler, içerik analizi yöntemiyle çözümlenmiştir.

İçerik analizine geçmeden önce verilerin düzenlenip sınıflandırılması gerekmektedir. Bu nedenle öncelikle veriler tasnif edilmiştir. Tasniflemenin gerçekleştirilmesinde kodlama cetveli geliştirilmiş ve bu süreçte araştırmanın güvenilirliğini sağlamak için araştırmacı teyidine ve uzman incelemesine başvurularak

\footnotetext{
• Ayrıntılı bilgi için bkz. Brand Finance, "Banking 500-2019, The Annual Report on the most Valuable and Strongest Banking Brands", Erişim Tarihi: 30.10.2019, https://brandfinance.com/images/upload/banking_500_2019_locked.pdf
} 
üçgenleme tekniklerinden (Başkale, 2016: 24-25) yararlanılmıştır. Nitel araştırmalarda güvenirliği sağlamak için birden fazla araştırmacının veri setlerini kodlayarak kodlar arasındaki tutarlılığın sağlanması gerektiğini belirten Miles ve Huberman, bu konuda [Güvenirlik = (Görüş birliği / Görüş birliği + Görüş ayrıllğı) X 100] formülünü (1994: 64) geliştirmiştir. Bu noktadan hareketle araştırmada alan uzmanı bir kodlayıcı ile birlikte çalışılmış ve iki araştırmacı öncelikle birbirinden bağımsız kodlama gerçekleştirmiştir. Araştırmanın güvenilirliğini artırmak için ayrı ayrı gerçekleştirilen ilk kodlama süreci tamamlandıktan sonra araştırmacılar bir araya gelerek uzlaşı sağlanan ve görüş ayrıllı̆ üzerinde uzlaşıldığı, 3 kodda görüş ayrıllı̆ yaşandığı saptanmıştır. Bu verilere göre Miles ve Huberman'ın (1994) formülünden yola çıkılarak kodlayıcılar arasındaki güvenilirlik ve uyum oranı \%90 olarak hesaplanmıştır. Akay ve Ültanır'a (2010: 80) göre kodlayıcılar arasındaki uyum oranının \%70’ten yüksek olması, kodlamanın yeterli güvenilirlikte olduğunu kanıtlamaktadır.

$\mathrm{Bu}$ çalışmada elde edilen \%90 oranına göre kodlayıcılar arası uyumun oldukça yüksek olduğu tespit edilmiştir. Bağımsız ilk kodlamada üzerinde uzlaşıya varılamayan üç kod, bu kez araştırmacıların bir araya gelmesiyle tartışılıp yorumlanmış ve bu süreç, kodlayıcıların fikir birliğine varmasına kadar devam etmiştir. Zira Silverman'a (2005) göre uzlaşılamayan kodlar üzerinde fikir birliğine varana kadar kodlayıcıların tartışmaları gerekmektedir. Bu nedenle tartışmalı kodlarda uzlaşı sağlanmasının ardından kodlama cetveline son şekli verilmiştir. Bu aşamadan sonra kodlama sürecini tamamlayabilmek ve araştırmanın güvenilirliği ile inandırıcılığını artırabilmek için üçgenleme tekniklerinden bir diğeri olan uzman görüşüne/incelemesine başvurulmuştur. Nitel araştırmalarda alan uzmanı kişilerin görüşlerinden yararlanmak ve onlardan geri bildirim almak, araştırmanın güvenilirliğini artıran bir faktör olarak kabul edilmektedir (Glesne ve Peshkin, 1992; Roberts ve Priest, 2006). Bu nedenle kodlama cetveli alan uzmanı bağımsız bir araştırmacı ile paylaşılmış ve elde edilen olumlu geri bildirim doğrultusunda kodlama süreci tamamlanmıştır. Böylelikle kurumsal blog kullanımı açısından en aktif üç bankanın, 5 Ekim ile 5 Aralık 2019 arasındaki iki aylık zaman diliminde bloğunda en son paylaştı̆̆ 10 içerik kategorize edilmiş ve bu bankaların blog kullanımına yönelik bulgular içerik analizi ile yorumlanmıştır.

\subsection{Bulgular}

Bankaların kurumsal blogları incelendiğinde araştırmanın gerçekleştirildiği 5 Ekim-5 Aralık 2019 tarihleri arasında en çok Teknoloji, Ekonomi, Gezi/Seyahat, Yararlı Bilgi, Sosyal Yaşam ve Etkinlik kategorilerine ait temaları ve içerikleri paylaştıkları gözlemlenmiştir. Bu kategorilerin bankalara göre dağılımları Tablo 1'deki gibidir.

Tablo 1. Bankalara Göre Kurumsal Blog Kategorilerinin Dağılımı

\begin{tabular}{|c|c|c|c|c|c|c|}
\hline \multirow{2}{*}{ BANKALAR } & \multicolumn{7}{|c|}{ KATEGORILER } & Etkinlik \\
\cline { 2 - 7 } & Teknoloji & Ekonomi & Gezi/Seyahat & Yararlı Bilgi & Sosyal Yaşam & - \\
\hline Garanti BBVA & - & 2 & - & 6 & 2 & - \\
\hline Türkiye İș Bankası & - & - & 1 & 5 & 6 & 2 \\
\hline TEB & 2 & - & - & - & $\mathbf{1 2}$ & $\mathbf{2}$ \\
\hline Toplam & $\mathbf{2}$ & $\mathbf{2}$ & $\mathbf{1}$ & $\mathbf{1 1}$ & $\mathbf{1 2}$ & \\
\hline
\end{tabular}

Tablo 1, araştırmaya dahil edilen üç bankanın blog kategorilerine göre içerik dağılımını özetlemektedir. Buna göre bankaların kurumsal bloglarında en son paylaşılan toplam 30 içeriğin üçte birinden fazlası, 12 paylaşım ile 'Sosyal Yaşam' kategorisine aittir. 'Sosyal Yaşam' kategorisini 11 paylaşım ile 'Yararlı Bilgi' kategorisi izlemiştir. 'Teknoloji', 'Ekonomi' ve 'Etkinlik' kategorilerine 2'şer paylaşım dağıllırken 'Gezi/Seyahat' kategorisinde 1 paylaşım tespit edilmiştir.

'Geleceğin Fırsatları Sizinle' sloganına sahip Garanti BBVA’nın kurumsal bloğunda, finans ve teknoloji alanında hayatı kolaylaştıracak çeşitli bilgiler sunulmaktadır. Bankanın blog kullanımında finans ve teknoloji alanındaki gelişmeleri birleştirdiği görülmektedir. Görsel 1, Garanti BBVA’nın kurumsal bloğundan yansıyan bir kesiti içermektedir. 


\section{Görsel 1. Garanti BBVA Kurumsal Blog Sayfası}

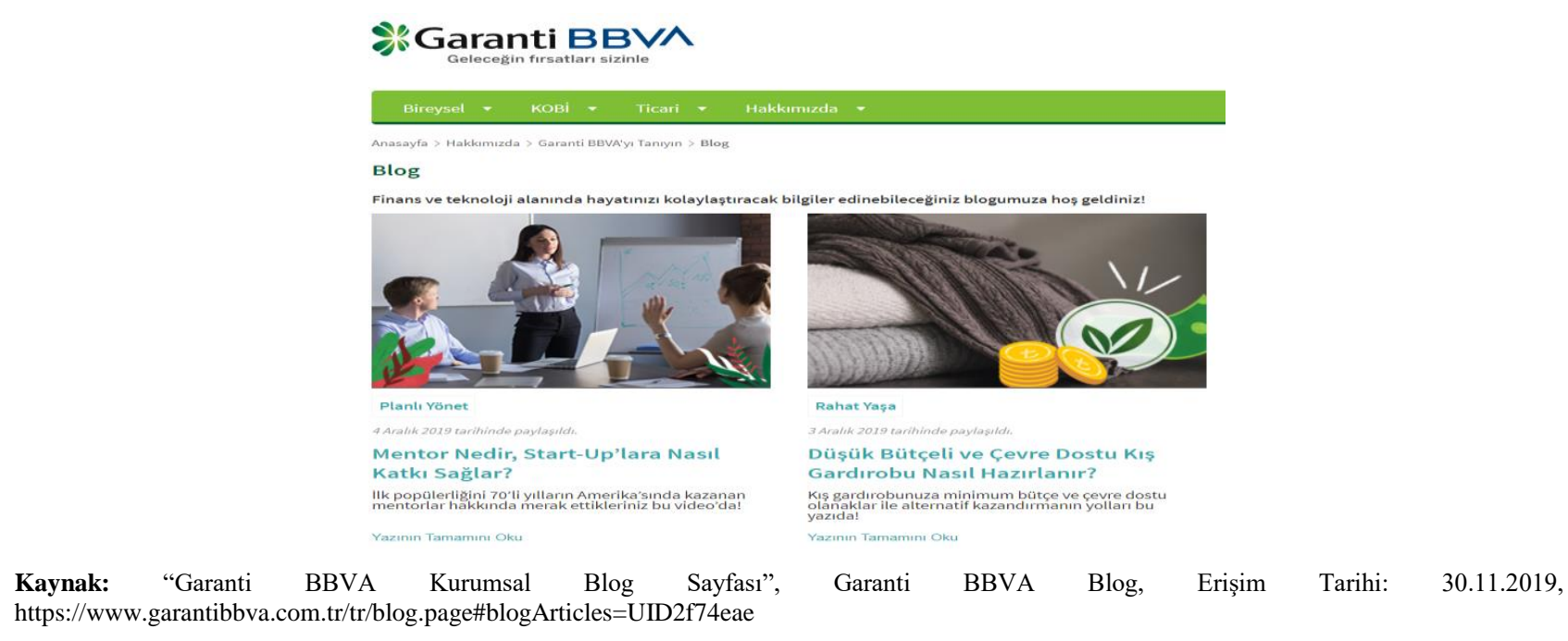

Görsel 1, Garanti BBVA'nın kurumsal bloğundan alınan ekran görüntüsünden oluşmaktadır. Bankanın kurumsal bloğunun; 'Kolay Biriktir', 'Planlı Yönet', 'Çağı Yakala' ve 'Rahat Yaşa' kategorilerindeki içeriklerden oluştuğu izlenmektedir. Garanti BBVA'nın bloğunda son paylaşılan 10 içerik şöyle siralanmaktadir:

1- Mentor Nedir, Start-Up'lara Nasıl Katkı Sağlar?

2- Düşük Bütçeli ve Çevre Dostu Kış Gardırobu Nasıl Hazırlanır?

3- Hem Eğlenceli Hem Ekonomik Kış Aktiviteleri

4- Araba Satın Almadan Önce Bu 5 Soruyu Kendinize Sorun

5- Sürdürülebilir Finansman ve İklim Değişikliği

6- Kış Kapıda: Doğal Gaz Faturalarınız İçin 6 Tasarruf Önerisi

7- Yeni Evli Çiftler İçin 5 Etkili Birikim Yöntemi

8- Hem KOBİ Hem de Girişimcilere Destek Veren Kurumlar

9- S1kça Sorulanlarla Beraber Bireysel Emeklilik Sistemi

10- Kişisel Net Değer Hesabı Nedir, Nasıl Yapı1ır?

Garanti BBVA'nın kurumsal bloğuna ait yukarıda sıralanan 10 paylaşımdan 6'sı Yararlı Bilgi, 2'si Ekonomi ve 2'si Sosyal Yaşam içeriğinden oluşmaktayken Teknoloji, Gezi/Seyahat ve Etkinlik kategorilerine ilişkin herhangi bir içerik tespit edilmemiştir. Garanti BBVA'nın kurumsal bloğunda öne çıkan kategorilere göre paylaşımlar şu içeriklerden oluşmuştur:

Yararlı Bilgi kategorisinde; Düşük Bütçeli ve Çevre Dostu Klş Gardırobu Nasıl Hazırlanır?, Araba Satın Almadan Önce Bu 5 Soruyu Kendinize Sorun, Kış Kapıda: Doğal Gaz Faturalarınız Için 6 Tasarruf Önerisi, Yeni Evli Çiftler İçin 5 Etkili Birikim Yöntemi, Hem KOBİ Hem de Girişimcilere Destek Veren Kurumlar ve Sikça Sorulanlarla Beraber Bireysel Emeklilik Sistemi ile ilgili paylaşımlar yer almıştır. Birinci içerikte, minimum bütçe ve çevre dostu olanaklar ile çevresel sürdürülebilirliğe katkı sağlayan alternatif kış gardırobunun nasıl hazırlanacağına ilişkin pratik bilgiler verilmiştir. İkinci içerik, sıfır ya da ikinci el araç satın alırken dikkat edilmesi gereken püf noktalara ve estetik kaygılar dışında düşünülmesi gereken temel sorulara verilmiş yanıtlardan oluşmuştur. Üçüncü içerikte, kış aylarında ev ekonomisinin temel gider başl1klarından biri olan ısınma maliyeti ele alınmış ve evde alınacak küçük önlemlerle doğal gaz faturalarında \%70'e varan tasarruf için 6 yararlı bilgi aktarılmıştır. Dördüncü paylaşım içeriğinde, yeni evli çiftlere yönelik ortak bütçe planlamasında birikim alışkanlıkları edinip geliştirmeye yönelik 5 etkili bilimsel tasarruf yöntemine yer verilmiştir. Beşinci içerikte, KOBI'ler ile girişimciler için destek, teşvik ve hibe sağlayan kurum ve kuruluşların bilgilerine yer verilerek bu kuruluşların ulusal ve küresel ekonomideki önemine değinilmiştir. Son içerikte ise en çok sorulan sorularla birlikte bireysel emeklilik sistemine ait temel bilgilere yer verilerek bu sistemde birikim yapmak için çeşitli ip uçları sunulmuştur.

Ekonomi kategorisi; Mentor Nedir, Start-Up'lara Nasıl Katkı Sağlar? ve Kişisel Net Değer Hesabı Nedir, Nasıl Yapılır?, paylaşımlarından oluşmuştur. İlk paylaşım içeriğinde, mentorların 1970'lerde öncelikle ABD'de popülerlik elde ettiği ve son dönemlerde yatırımcılarla ilişkilerde daha istikrarlı iş birlikleri 
kurulmasında etkili olduğu üzerinde durularak girişimciliğin ekonomideki önemine değinilmiştir. Son içerikte ise kişisel net değeri hesaplamaya ilişkin formül paylaşılmış ve finans ve ekonomi uzmanlarının gelir yönetimi için en işlevsel yöntemleri derlenerek kişisel ekonomi yönetimine katkı sağlanmıştır.

Sosyal Yaşam kategorisinde; Hem Ĕglenceli Hem Ekonomik Kış Aktiviteleri ile Sürdürülebilir Finansman ve İklim Değişikliği konulu paylaşımlar değerlendirilmiştir. Bu paylaşım içeriklerinden birincisinde, kış aylarındaki soğuk hava koşullarında bile düşük bütçeli ve keyifli aktiviteler yapmanın mümkün olduğu vurgulanarak kış aylarında bütçeyi sarsmadan sosyal yaşamdan geri kalmamak için çeşitli önerilerde bulunulmuştur. İkinci içerik ise küresel sıcaklığın tehdit edici boyutlara ulaştığına işaret ederek sürdürülebilir kalkınma ve çevresel ekosistemi korumak için sosyal yaşamda herkesin üzerine düşen sorumluluklar olduğuna dikkat çekilmiştir.

Garanti BBVA'nın kurumsal bloğunda öne çıkan paylaşım içeriklerinde sıklıkla yararlı bilgilere, ekonomiye dair ip uçları ile sosyal yaşamı kolaylaştıran çeşitli önerilere ve dikkat çekici konulara yer verdiği gözlemlenmiştir. Bankanın kurumsal bloğundaki bu içerikleri, herkesin anlayabileceği bir dille sohbet havasında ve samimi bir tonda paylaştığı dikkat çekmiştir. "Bloglarda kurulan samimi ortamların ve bloglarda kullanılan çift yönlü iletişimin, kurumlara duyulan güvensizliği büyük oranda ortadan kaldırdığına işaret edilmektedir" (Alikılıç, 2011: 28). Bu noktada Garanti BBVA'nın kurumsal blog kullanımında çeşitli konulara yer verip hedef kitleleri ve paydaşları arasında samimi bir ortam geliştirdiğini söylemek mümkündür. Akar'a (2006: 71-72) göre kurumsal bloglar, mevcut ve potansiyel müşterileri etkilemekte, kurum lehine olumlu bir algıya sahip olmalarına yardımcı olmaktadır. Zira müşteriler, kurumsal bloglar aracılığıyla kurumları yakın bir dost olarak algılamakta ve kurumla yakın ve samimi ilişki kurmaya gönüllü hale gelmektedir. Bunun sonucunda müşteri memnuniyeti artmakta ve kuruma sadık müşteri profilinin ortaya çıkması da kolaylaşmaktadır. Garanti BBVA açısından değerlendirilecek olursa bankanın kurumsal blog kullanımı ile kurumsal halkla ilişkiler faaliyetlerini dijital platformda da sürdürmeyi ve müşteri memnuniyetini geliştirmeyi hedeflediği söylenebilmektedir.

Çalışmada incelenen diğer bir banka olan Türkiye İş Bankası'nın 'Hayatınızın Her Anındayız' temalı kurumsal bloğunda çeşitli kategoriler karşımıza çıkmaktadır. Görsel 2, Türkiye İş Bankası'nın kurumsal bloğuna ait ekran görüntüsünü yansıtmaktadır.

\section{Görsel 2. Türkiye İş Bankası Kurumsal Blog Sayfası}

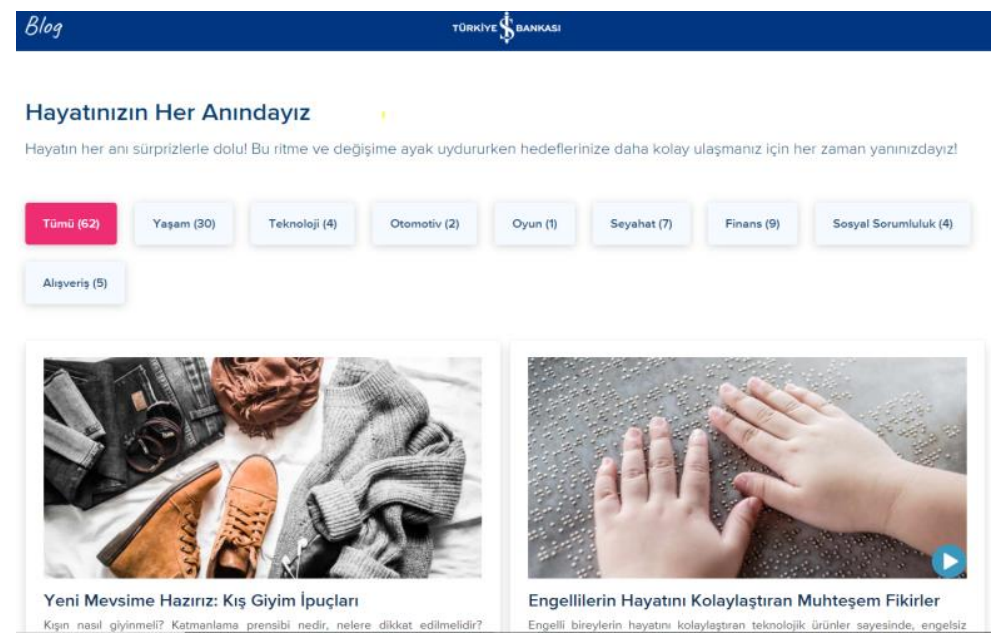

Kaynak: “Türkiye İş Bankası Kurumsal Blog Sayfası”, Türkiye İş Bankası Blog, Erişim Tarihi: 30.11.2019, https://www.isbank.com.tr/blog

Görsel 2’de Türkiye İş Bankası'nın kurumsal blog sayfasından bir görünüm sunulmuştur. Bankanın blog sayfasında 'Yaşam', 'Teknoloji', 'Otomotiv', 'Oyun', 'Seyahat', 'Finans', 'Sosyal Sorumluluk' ve 'Alışveriş' temaları öne çıkmaktadır. Blogda son paylaşılan 10 içerik şöyledir:

1- Yeni Mevsime Hazırız: Kış Giyim İp Uçları

2- Engellilerin Hayatını Kolaylaştıran Muhteşem Fikirler

3- Evde Çocuğunuzda Beraber Yapabileceğiniz 5 Aktivite

4- Yılbașı Tatili İçin Yurt Dıșında Gidilebilecek Yerler

5- Kıșın Evde Yapılabilecek Aktiviteler

6- Bilinçli Tüketici Olmak! 6 Adımda Besin Etiketi Okuma Taktikleri

7- Hazırlıklı Olmak Hayat Kurtarır! Doğal Afetlere Karşı Alınacak Önlemler 
8- Şeker Hastalığı Hakkında Ne Biliyoruz, Ne Yapıyoruz?

9- Zamanınızı Güzelleştirecek Mutlaka Okunması Gerekli Kitaplar

10- Çocukların Mutlaka Okuması Gereken Kitaplar

Türkiye İş Bankası'nın kurumsal bloğunda yukarıda sıralanan en son 10 paylaşımın 5'i Yararlı Bilgi, 4'ü Sosyal Yaşam ve 1'i Gezi/ Seyahat içeriklerine aitken Teknoloji, Ekonomi ve Etkinlik kategorilerine girecek herhangi bir paylaşım içeriği saptanmamıştır. Türkiye İş Bankası'nın kurumsal bloğunda öne çıkan kategoriler ve paylaşım içerikleri şöyledir:

Yararlı Bilgi kategorisi; Yeni Mevsime Hazırız: Kış Giyim İp Uçları, Engellilerin Hayatını Kolaylaştıran Muhteşem Fikirler, Bilinçli Tüketici Olmak! 6 Adımda Besin Etiketi Okuma Taktikleri, Hazırlıkl Olmak Hayat Kurtarır! Doğal Afetlere Karşı Alınacak Önlemler ve Şeker Hastalı̆̆ı Hakkında Ne Biliyoruz, Ne Yapıyoruz?, başlıklı paylaşımlardan oluşmuştur. İlk içerikte, kışın hasta olmamak, soğuklardan korunmak, daha az üşümek, vücut direncini artırmak ve soğuk havalarda bile dışarıda kaliteli vakit geçirebilmek için nasıl giyinilmesine gerektiğine yönelik faydalı bilgiler sunulmuştur. İkinci içerikte, dünya çapında birçok farkındalık etkinliğinin yapıldığı 3 Aralık Dünya Engelliler Günü kapsamında engelli bireylerin toplumla bütünleşmesine katkıda bulunacak, sosyal yaşama katılımlarını artıracak, kendilerini geliştirmelerini sağlayacak ve hayatlarını kolaylaştıracak pratik bilgiler eşliğinde engelsiz yaşam projeleri tanıtılarak engelli bireylerin toplumsal yaşamda karşılaştıkları çeşitli zorluklara dikkat çekilmiştir. Üçüncü içerikte, bilinçli tüketici olmak için paketin içindeki gıdanın porsiyonunu, kalorisini ve içindeki maddelerin bilgisini içeren ve ürünü satın almadan önce içeriği hakkında fikir sahibi olmamızı sağlayan besin etiketi okuma hakkında bilgi verilmiş; besin etiketlerinin kolayca okunmasını sağlayacak faydalı bilgiler sunularak besin etiketi okumanın dengeli beslenme ve kilo kontrolü üzerindeki önemine değinilmiştir. Dördüncü içerikte, 12 Kasım Doğal Afetlerden Korunma Günü kapsamında deprem başta olmak üzere sel, çığ ve heyelan gibi çeşitli doğal afetler hakkında bilgiler verilmiş ve tanımlanan doğal afetlere ilişkin alınması gereken basit ama hayat kurtaran önlemlere dikkat çekilmiştir. Son içerikte ise Dünya Diyabet Günü olarak çeşitli etkinlikler yapılan 14 Kasım'daki yazıda, öncelikle şeker hastalığı tanımlanıp şeker hastalığının öne çıkan belirtilerine yer verilmiş ve şeker hastalığını önlemede beslenme ve spor alışkanlıklarının önemi vurgulanarak şeker hastalarının tedavisinde uygun diyet, spor ve beslenme önerileri sunulmuştur.

Sosyal Yaşam kategorisinde; Evde Çocuğunuzda Beraber Yapabileceğiniz 5 Aktivite, Klşın Evde Yapılabilecek Aktiviteler, Zamanınızı Güzelleştirecek Mutlaka Okunması Gerekli Kitaplar ve Çocukların Mutlaka Okuması Gereken Kitaplar, başlıklı paylaşımlar yer almıştır. Birinci içerikte, evde çocuklarla birlikte geçirilen zamanın kalitesini artırmak ve çocuklarla yapılan aktivitelerde daha çok eğlenmek için yaratıcı oyunlar, çocuklarla iş birliği içerisinde gelişen eğlenceli aktiviteler ve çocukların el becerilerini geliştiren çeşitli uğraşlara yönelik önerilerde bulunarak bu aktivitelerin çocuk ve ebeveyn ilişkisini güçlendirmedeki önemine değinilmiştir. İkinci içerikte, kışın kapalı ve soğuk havalarda düşen enerjiyle dışarı çıkmak istenmediği zamanlarda bile kış mevsimini evde keyifle ve eğlenceyle geçirmek için yaratıcı öneriler, dekorasyon tavsiyeleri, evde sosyalleşmeyi sağlayacak etkinlik fikirleri paylaşılmıştır. Üçüncü içerikte kitapların, sosyal yaşamda keyifli zaman geçirmek, gündelik kaostan kurtulmak, kafa boşaltmak, kendimize yatırım yapmak ve yeni bir şeyler öğrenmek için en güzel aktivitelerden biri olduğu vurgulanarak değerli zamanlar geçirmemizi sağlayacak ve Türkiye İş Bankası Kültür Yayınları'ndan çıkan çeşitli romanlar tavsiye edilip kısaca özetlenmiştir. Son içerikte ise çocukların merak duygusunun cezbedilerek kitap okuma alışkanlığı kazanmaları ve hem ruhsal hem de zihinsel gelişimlerini desteklemek için Türkiye İş Bankası Kültür Yayınları'ndan çıkan ve mutlaka okumaları tavsiye edilen çocuk kitapları derlenmiş ve bu kitaplar kısaca tanıtılmıştır.

Gezi/Seyahat kategorisinde ise Yılbaşı Tatili İçin Yurt Dışında Gidilebilecek Yerler, başlıklı paylaşıma yer verilmiştir. $\mathrm{Bu}$ içerikte, yeni bir yılı ve yeni umutları simgeleyen yılbaşı tatilinin en güzel tarafinın bulunduğumuz yerden biraz uzaklaşmak, bilmediğimiz farklı yerlerde bulunmak ve yurt dışında daha önce gidilmemiş yerleri gezip görmek olduğuna işaret edilerek yılbaşında Prag, Paris, Lviv, Brugge, Rio de Janeiro ve Londra gibi dünya genelinde en popüler, romantik ve ilgi çekici rotalar belirlenmiştir.

Türkiye İş Bankası'nın kurumsal bloğunda sıkça kullanılan içerikler arasında yaşamı kolaylaştıracak pratik bilgilere ve ip uçlarına, sosyal yaşamda herkesin kolaylıkla gerçekleştirebileceği tavsiyelere ve yılbaşı tatilinde yurt dışında gezilebilecek şehirler gibi önerilere yer verilmiştir. Bankanın kurumsal bloğunda öne çıkan bu içerikler ile hedef kitleler ve paydaşlar arasında etkileşim düzeyini yükseltmek istediğini söylemek 
mümkündür. Bankanın bloğunda herkesin ilgisini çekecek güncel konulara yer verildiği dikkat çekmektedir. Nitekim kurumsal bloglar, kurumların iç ve dış hedef kitleleri ile iletişimin sürekliliğini sağlamada önem taşıyan kanallardan biri olarak karşımıza çıkmaktadır. Kurumlar, sosyal medyaya taşınan iletişim süreçlerinde bloglarını güncel veriler ile canlı ve ilgi çekici tutarak müşterilerini bu konular hakkında kolaylıkla ve memnuniyet yaratacak şekilde haberdar etmeye çalışmaktadır (Kılıç, 2011: 144). Türkiye İş Bankası'nın kurumsal bloğu üzerinden canlı tutmaya çalıştı̆̆ müşteri ilişkileri yönetimi, bankanın bloğundan kurumsal halkla ilişkiler amaçlı yararlandığının da göstergesidir. Zira kurumsal bloglar, kurumların hedef kitleleri ile aralarında sağlıklı bir diyalog ve geri bildirim sürecinin başlatılıp etkileşim ve ilişki inşa edilmesi yoluyla bu sürecin sürdürülüp geliştirilmesi açısından önemli rol oynamaktadır (Yang ve Lim, 2009: 342). Türkiye İş Bankası açısından değerlendirildiğinde bankanın kurumsal bloğundan halkla ilişkiler aracı olarak yararlanması söz konusudur.

Araştırma kapsamında incelenen son banka olan TEB'in http://www.blogteb.com/ adresinden ulaşlan ve herhangi diğer iki bankada görüldüğü gibi özel bir tema içermeyen kurumsal bloğunda ilgili kategoriler sıralanmıştır. Görsel 3’te TEB'in kurumsal bloğundan alınan ekran görüntüsü sunulmuştur.

\section{Görsel 3. TEB Kurumsal Blog Sayfası}

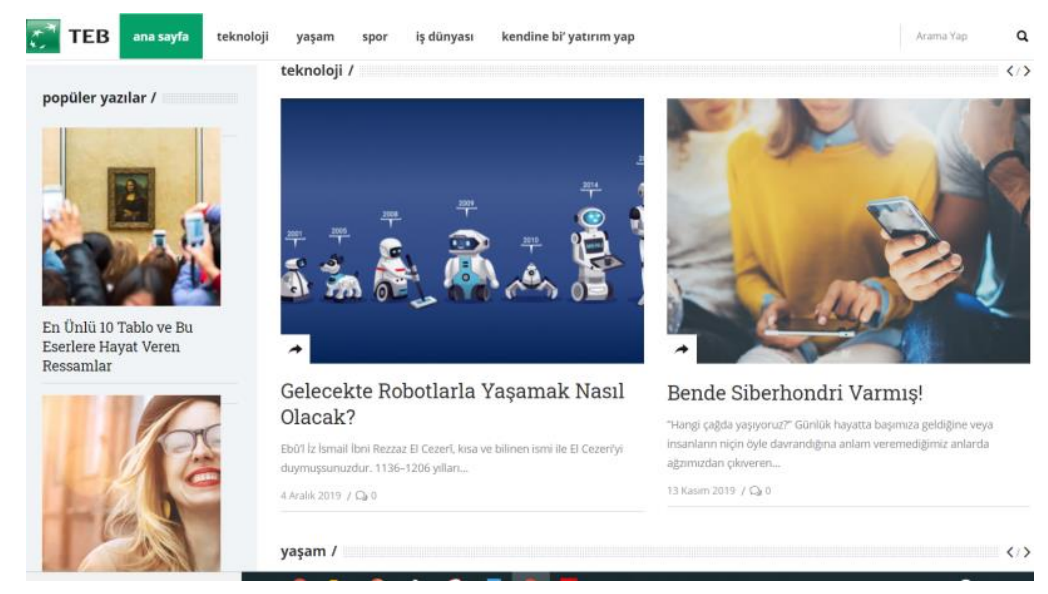

Kaynak: “TEB Kurumsal Blog Sayfası”, TEB Blog, Erişim Tarihi: 30.11.2019, http://www.blogteb.com/

Görsel 3, TEB'in kurumsal blog sayfasının görüntüsünü içermektedir. Buna göre TEB'in bloğunda; 'Teknoloji', 'Yaşam', 'Spor', 'İs Dünyası' ve 'Kendine bi' Yatırım Yap' başlıklı temalara ait içeriklere yer verdiği izlenmektedir. TEB kurumsal blog sayfasında paylaşılan son 10 içeriğin başlığı şu şekildedir:

1- Gelecekte Robotlarla Yaşamak Nasıl Olacak?

2- Bende Siberhondri Varmış!

3- "Süper" Yetenek: İkna Kabiliyeti

4- Yeni Nesil Sanatçıların Elinden Sanatın Her Hali BASE 2019'da

5- Sporun Her Halini İzleyebileceğiniz İlham Veren Filmler

6- Mağara Duvarlarından Yapay Zekâ Sanatına Sanatın Büyüleyici Yolculuğu

7- "Formaları Emekli Edilerek" Onurlandırılan Spor Efsaneleri

8- Tarihin Yönünü Değiştirenlerde Bugün: Minik Dev iPod!

9- Dijital Pazarlama Yöntemlerinden "Conversational Marketing (Sohbet Pazarlamas1)" Yükselişte

10- Bankacılık Ürün ve Hizmetlerine Yönelik Harika Bir Fikrin Varsa İcat Çıkarmaya Ne Dersin?

TEB'in kurumsal bloğunda yukarıda sıralanan ve en son paylaşılan 10 içeriğe göre bu içeriklerin 6'sı Sosyal Yaşam, 2'si Teknoloji ve 2'si Etkinlik kategorisindeyken Ekonomi, Gezi/Seyahat ve Yararlı Bilgi kategorisinde herhangi bir paylaşım tespit edilmemiştir. TEB'in kurumsal bloğunda karşımıza çıkan kategoriler doğrultusunda yer alan paylaşım içerikleri aşağıdaki gibidir:

Sosyal Yaşam kategorisi; Gelecekte Robotlarla Yaşamak Nasıl Olacak?, Bende Siberhondri Varmış!, "Süper" Yetenek: İkna Kabiliyeti, Sporun Her Halini İzleyebileceğiniz İlham Veren Filmler, Mağara Duvarlarından Yapay Zekâ Sanatına Sanatın Büyüleyici Yolculuğu ve "Formaları Emekli Edilerek" Onurlandırılan Spor Efsaneleri, başlıklı paylaşımlardan oluşmuştur. İlk paylaşım içeriğinde, geçmişten günümüze yapay zekâ ile robotik alanda yaşanan gelişmelere yer verilmiş ve gelecek projeksiyonu üzerinde durularak sosyal yaşamı tehdit eden komplo teorilerine değinilmiştir. İkinci içerikte, teknolojik gelişmelerin ortaya çıkardığı yeni kavramlardan biri olan 'siberhondri' (rahatsızlık belirtilerini internetten araştırıp kendine 
hastalık tanısı koyma) konu edilmiş ve sosyal yaşamda bizleri bekleyen diğer tehlikelere ve dijital çağ bağımlılıklarına dikkat çekilmiştir. Üçüncü içerikte, sosyal yaşamın her alanında herkesin ihtiyaç duyduğu bir yetenek olarak tanımlanan ikna kabiliyetine yer verilmiş ve kariyer basamaklarını başarıyla tırmanabilmek için iş yaşamında ikna etmenin önemi aktarılmıştır. Dördüncü içerikte, Muhammed Ali ve Maradona gibi topluma mâl olmuş önemli sporcuların yaşamını anlatan ve herkesin keyifle izleyip kendi yaşamında motivasyon sağlamak için kullanabileceği güç verici filmler derlenmiştir. Beşinci içerikte, insanlık tarihinin başlangıcından bu yana sanatın gösterdiği gelişim konu edilmiş ve insanın yaşam serüveni içerisinde sanatın büyüleyici yolculuğu, tarih öncesi çağlardan günümüzdeki güncel örnekler eşliğinde sunulmuştur. Son içerikte ise elde ettikleri başarılar ile taraftarların kalbinde yaşayan ve oynadıkları kulüplerde forma numaraları emekli edilerek isimleri ölümsüzleşen Türk ve yabancı en ünlü basketbolcular ve futbolcular konu edilmiştir.

Teknoloji kategorisinde Tarihin Yönünü Değiştirenlerde Bugün: Minik Dev iPod! ve Dijital Pazarlama Yöntemlerinden "Conversational Marketing (Sohbet Pazarlaması)" Yükselişte, başlıklı paylaşımlar yer almıştır. Birinci içerikte, kişisel müzik dinleme deneyimini olağanüstü bir seviyeye taşıyan ve müzik endüstrisini değiştiren ilk iPod'un 2001 yılında çıkmasının ardından 2019 yılında güncellenen ve piyasaya sürülen 7. nesil iPod Touch'ın teknolojik özellikleri ve avantajları anlatılmıştır. Diğer içerikte ise teknolojinin gelişmesi sonucunda 'sohbet pazarlaması' ile akıllı yönlendirmeye, yapay zekâ destekli 'rehber robot' uygulamalarına (ChatBot) ve 7/24 hizmete hazır satış temsilciliği stratejilerinin artık teknolojinin en önemli parçası olduğuna yer verilmiştir.

Etkinlik kategorisinde ise Yeni Nesil Sanatçıların Elinden Sanatın Her Hali BASE 2019'da ve Bankacılık Ürün ve Hizmetlerine Yönelik Harika Bir Fikrin Varsa İcat Çıkarmaya Ne Dersin?, başlıklı paylaşımlara yer verilmiştir. İlk içerikte, Türkiye'deki Güzel Sanatlar Fakülteleri'nden çıkan yeni mezunlar tarafından oluşturulan animasyon, baskı, cam, fotoğraf, grafik tasarım, heykel, resim, seramik gibi alanlarda ilk kolektif sergi olan BASE'in, 2019 yılında üçüncüsü düzenlenen etkinliği yer almıştır. Son içerikte ise TEB'in üniversite öğrencilerine, yeni mezunlara, TEB müşterilerine ve girişimcilere yönelik sektöre yenilikçi ve yaratıcı ürünler kazandırmak, müşteri deneyimini iyileştirmek ve inovasyon kültürünü yaygınlaştırmak amacıyla "İcat Çıkar” sloganına sahip 13.sünü 15 Ocak 2020'de düzenleyeceği TEB Akı1 Fikir Yarışması konu edilmiştir.

TEB'in kurumsal bloğunda, son paylaş1lan içeriklere göre en çok sosyal yaşamda zaman geçirmek ve eğlenmek amaçlı başvurulacak keyifli içeriklere, teknolojik gelişmelere ve bu gelişmelerin yaşamımıza getireceği yenilikler ile kültür, sanat ve inovasyonla ilgili çeşitli etkinliklere yer verildiği gözlemlenmiştir. Bankanın kurumsal bloğunda ağırlıklı olarak yer verilen bu içeriklerde, yaşamı kolaylaştıran pratik bilgilerden ve ip uçlarından doğrudan bahsedilmemiş olsa da sosyal yaşam kategorisindeki belirli içeriklerin, yararlı bilgi formatı ile de eşleştiği görülmüştür. Ancak bankanın çoğunlukla sosyal yaşam kategorisine yönelik bilgi ve eğlenceyi harmanladığı içerikleri paylaşarak mevcut ve potansiyel müşterileri ile sıkıcılıktan ve tekdüzelikten uzak, daha samimi bir etkileşim yaratmak istediği söylenebilmektedir. Porter ve diğ. (2009: 252), kurumsal blogların kurum ve hedef kitleleri arasında resmî olmayan samimi iletişim kurulmasını ve dijital ortamlarda ağızdan ağıza iletişimi kolaylaştıran dinamik bir etkileşim izlenmesini sağladığını belirtmektedir. Zira kurumsal bloglar, müşteriler arasında topluluk bilinci yaratarak kuruma ve markaya bağlılığı geliştirmekte ve sosyal medyada ağızdan ağıza pazarlamanın etkinliğini artırmaktadır (Özüdoğru, 2014: 42). Benzer şekilde Philip (2017: 65) de sosyal medya ile halkla ilişkilerin rollerinin ve görevlerinin değişip geliştiğine dikkat çekerek kuruluşların, küresel rekabete dayanabilmek için sağlıklı ve sürdürülebilir ilişkiler kurması gerektiğgine ve kurumların güçlü birer marka olarak müşterilerin zihinlerinde yer edinebilmesi için kurumsal blogların önemli bir araç olduğuna işaret etmektedir. Bu noktada TEB'in, kurumsal halkla ilişkiler amaçlarına ulaşmada blogların taşıdığı önemin farkında olduğu ve farklı içeriklerle bloğunu zenginleştirmeye yönelik bir çaba sergilediğini söylemek mümkündür. Buna göre kurumsal halkla ilişkiler ve kurumsal bloglar arasında önemli bir bağlantı bulunduğu görülmektedir. Kurumsal halkla ilişkilere ait olan tüm işlevler, günümüzde sosyal medyada da devam etmektedir. Bu noktada özellikle kurumsal bloglar, kurumsal halkla ilişkilerin dijital platformda uygulanmasına yardımcı olan etkili araçlardan biri olarak karşımıza çıkmaktadır.

\section{DEĞERLENDİRME VE SONUÇ}

Kurumsal halkla ilişkilerin genel olarak; çift yönlü iletişim ile etkileşim sağlama, diyalog geliştirme, bağlantı ve ilişki inşa etme, kurumun imajını ve itibarını güçlendirerek kuruma yönelik marka değeri yaratma, hedef kitleler ile paydaşlar arasında kurum lehine güven ortamı kurma, krizleri ortaya çıkmadan önleme, sorun

Selçuk Üniversitesi Sosyal Bilimler Meslek Yüksekokulu Dergisi, Yıl: 2020 Cilt: 23 Sayı:2 
ve gündem yönetiminde etkili olma, başarılı müşteri ilişkileri yönetimi ile sadık müşteriler elde etme gibi temel işlevlerinden söz etmek mümkündür. Ancak bunlar arasında en önemlisi, hedef kitleler ile sürekli bir etkileşim ve ilişki kurulmasını sağlamaktır. Sosyal medya ile kurumsal halkla ilişkiler de dijital ortamlara taşınmış ve çift yönlü iletişim, diyalog, etkileşim ve ilişki kurma işlevi kolaylaşmıştır. Sosyal medyada bu işlevi yerine getirecek önemli araçlardan birinin de kurumsal bloglar olduğu ortadadır. Ancak buna rağmen, incelenen üç bankanın kurumsal bloglarında, çift yönlü iletişim ve etkileşim ortamı yaratacak diyaloglara ve yorumlara rastlanmamıştır. Dolayısıyla kurumsal banka bloglarının, kurumsal halkla ilişkiler açısından büyük bir potansiyele sahip olduğunu ancak bu potansiyelden tam anlamıyla ideal şekilde yararlanılamadığını söylemek mümkündür.

5 Ekim-5 Aralık 2019 tarihleri arasında gerçekleştirilen araştırma sonuçlarına göre bankaların kurumsal bloglarında en çok paylaşılan içeriklerin sırasıyla; 'Sosyal Yaşam', 'Yararlı Bilgi', 'Ekonomi', 'Teknoloji', 'Etkinlik' ve 'Gezi/Seyahat' kategorisine ait olduğu izlenmiştir. Buna rağmen kategorilerin dağılımı bankalara göre değişiklik göstermiştir. Garanti BBVA'nın en çok Yararlı Bilgi, Ekonomi ve Sosyal Yaşam kategorilerine yoğunlaştığı; Teknoloji, Gezi/Seyahat ve Etkinlik alanında herhangi bir paylaşım yapmadığı görülmüştür. Türkiye İş Bankası'nın ağırlıklı olarak Yararlı Bilgi, Sosyal Yaşam ve Gezi/Seyahat kategorilerine ilişkin içerikler üzerinde durduğu ancak Teknoloji, Ekonomi ve Etkinlik kategorisinde bir içerik üretmediği dikkat çekmiştir. TEB'in ise sıklıkla Sosyal Yaşam, Teknoloji ve Etkinlik kategorilerini besleyen içeriklerden yararlandığı ancak Ekonomi, Gezi/Seyahat ve Yararlı Bilgi içeriklerine yer vermediği saptanmıştır. Üç bankanın da en çok 'Sosyal Yaşam' kategorisine yönelik eğlenceli içeriklerden yararlandığı izlenmiş ve Sosyal Yaşam kategorisi, içerik paylaşımına göre ilk sırada yer almıştır. İkinci sırada yer alan 'Yararlı Bilgi' kategorisinde Garanti BBVA ve Türkiye İş Bankası'nın hemen hemen aynı oranda içerik ürettiği dikkat çekerken TEB'in bu kategoride herhangi bir içeriği görülmemiştir. 'Teknoloji', 'Ekonomi' ve 'Etkinlik' kategorileri 2'şer içerik ile üçüncü sırayı paylaşmıştır. 'Teknoloji' ve 'Etkinlik' kategorileri, 2'şer paylaşım ile sadece TEB' in içeriklerinden oluşmuştur. 'Ekonomi' kategorisinde de yalnızca Garanti BBVA'nın içerik paylaştığı tespit edilmiştir. Son sırada yer alan 'Gezi/Seyahat' kategorisi ise sadece Türkiye İş Bankası tarafından içeriklendirilmiştir.

Dolayısıyla incelenen üç bankanın, kategorilere göre üstünlükleri ve zayıflıkları söz konusudur. Oysa sosyal medyada kurumsal blog kullanımı, hedef kitleler için her alanda ilgi çekici ve kaliteli içerikler üreterek ve bu içerikleri sık güncelleyerek kurumun zihinlerde konumlanmasına, içeriklere yorum bırakılarak tartışma ortamının ve dolayısıyla kurum ile hedef kitleler arasında etkileşim, ilişki ve diyalog potansiyelinin gelişmesine katkıda bulunmaktadır. Bu araştırmanın karşımıza çıkardığı bulgu, Özel ve Sert'in (2014), Türkiye'nin En Büyük 500 Özel Şirketini blog kullanım açısından değerlendirdikleri çalışmada, Türkiye'deki kurumsal blogların toplam blog kalite indeksi değerinin düşük olduğu sonucuyla örtüşmektedir. Aynı zamanda bu bulgular, Philip'in (2017) blogların kurumsal aidiyet ihtiyacını karşılama ve kurumun oynadığı rolü vurgulama üzerine gerçekleştirdiği çalışmasında, blogların etkili diyalog iletişimi konusunda eğitimli kişiler tarafından hazırlanıp yönetilmesi gerektiğine ilişkin sonuçlarla da benzeşim taşımaktadır.

Araştırma bulgularından elde edilen sonuçlara göre banka bloglarının, kurumsal halkla ilişkiler aracı olarak güçlendirilmesi gereken çeşitli alanları olduğu tespit edilmiştir. Öncelikle kurumsal blogların, hedef kitleler ile istenen etkileşim, diyalog ve ilişki düzeyini yakalayabilmesi için kullanıcı yorumlarına izin veren bir yapıya sahip olması gerekmektedir. Oysa incelenen üç bankanın bloğunda herhangi bir yorumun bırakılmasına olanak verilmediği saptanmıştır. Bu durumu, kurumların olumsuz eleştirilerden çekinmesi, olumsuz yorumlara nasıl tepki verileceğinin bilinmemesi ve kurum imajı ile itibarının zarar göreceği endişesi ile açıklamak mümkündür. Ortaya çıkan bu sonuç, Buluthan'ın (2014) Türkiye'de faaliyet gösteren firmalar açısından kurumsal blogların kurumsal iletişim amacıyla nasıl kullanıldığını incelediği çalışmasında, çoğu bloğun yorum yapilmasına izin vermediği bulgusunu doğrulamaktadır. Söz konusu bulgu Pitt ve diğg. (2011) tarafından gerçekleştirilen çalışmada, blogların etkileşimli kaynaklar olarak kullanıcıların daha fazla yorumuna izin verecek şekilde geliştirilmesi gerektiği sonucu ile de benzerlik taşımaktadır. Kurumsal blogların, güncel tartışmaların gerçekleştirilip yorumların bırakılabileceği dijital platformlar olması, kurumsal halkla ilişkiler açısından önemli görülmektedir. Zira kamuoyunun güncel nabzını ölçümleyebilmek, kurumun hedef kitleler nezdindeki konumunu izleyebilmek, kurumu yakından ilgilendiren ve gelecekte potansiyel kriz riski taşıyan konuları öğrenebilmek, hedef kitlelerin ve paydaşların isteklerini, beklentilerini veya şikayetlerini takip edebilmek, elektronik ağızdan ağıza pazarlamayı başarılı şekilde yönetebilmek için bloglar bulunmaz bir firsattır.

Bunun yanı sıra bankaların kurumsal bloglarında, herkese hitap eden kategorilerin çeşitlendirilip her kategoriye ait kaliteli ve dikkat çekici içeriklerin üretilmesi gerekmektedir. Araştırma sonuçları, bankaların belirli kategorilere yoğunlaştığını ve diğer kategorileri göz ardı ettiğini göstermiştir. Oysa her hedef kitleye hitap eden içeriklerin üretilip kurumdan istenen şekilde söz edilmesini sağlayacak elektronik ağızdan ağıza 
pazarlama gibi iletişim stratejilerini uygulamak ve yönetmek, günümüzde kurumsal bloglar ile mümkün ve kolay bir hale gelmiştir. Yine araştırma sonuçlarına göre her üç bankanın blog kullanımında görsel, yazılı ve işitsel içeriklerden yararlanıldığ saptanmıştır. Bu durumu, bankaların çok sayıda ve çeşitli mesajlara maruz kalan hedef kitleleri yakalamak ve ilgilerini istenen noktaya çekmek amacıyla iletişim kanallarının artırılmaya çalışılması amacı ile ifade etmek mümkündür. Yazılı metinlere uygun fotoğraflar veya kısa videolar gibi görsel içeriklerin yoğun şekilde kullanıldığı, yazılı ve görsel içeriklerin neşeli ve enerjik müzik seçimleri ile eşleştirildiği görülmüştür. Sadece tek iletişim kanalından aktarılan içerik sayısı yok denecek kadar azdır. Genellikle birden fazla iletişim kanalının kullanıldığı izlenmiştir. Bu sonuç, Doroschuk ve Staroverova'nın (2017), bloglardaki içerik kullanımına odaklandıkları çalışmada, blogların çevrim içi sunumların çekirdeğini oluşturduğu ve bu nedenle zengin içerik formatıyla sunulması gerektiği bulgularıyla benzeşim göstermiştir. Bu noktada blogların, kurumsal halkla ilişkilerin en önemli parçalarından biri olduğunun unutulmaması ve bu doğrultuda bilinçli şekilde kullanılması gerekmektedir.

Elde edilen bu sonuçlara göre kurumsal halkla ilişkiler odaklı yaklaşımdan hareket ederek blogların içerik kalitesini artırmak ve müşterilerle sürdürülebilir iletişimi güçlendirmek için kurumsal blogların güncelliğine dikkat edilmesi önem arz etmektedir. Bu kapsamda fotoğraf, video veya GIF (hareketli grafik) gibi farkl1 biçimlerle blogların görsel olarak daha çekici hale getirilmesi ve zengin güncel içerik sunulması gerekmektedir. Bunun yanı sıra kurumsal blog bağlantılarının (link) kurum sayfası içerisinde ayrı bir sekme olarak yer alması hem takipçileri ve/veya müşterileri kurum ile iletişim içerisine girmeye yönlendirmesi hem de kurumun iletişime açık tavrını yansıtması açısından önem taşımaktadır. Kurumsal blogların, müşterilerden gelen olumlu ve olumsuz yorumlara izin veren ve katılımcılığ özendiren iletişim tasarımına sahip olması önemli bir noktadır. Zira yoruma açık kurumsal bloglar, kurumların şeffaflığının önemli bir göstergesi olduğu gibi müşterilerden gelen geri bildirimler doğrultusunda etkin konu yönetimi yapılabilmesi, kriz iletişiminin doğru yönetilebilmesi ve nihayetinde hizmet kalitesinin iyileştirilmesi açısından da değerli firsatlar sunmaktadır. Dolayısıyla kurumsal bloglar; çift yönlü iletişime ve etkileşime olanak veren, diyalog geliştirip tartışma ve yorumlarla zenginleşen, bunun sonucunda hedef kitleler ile ilişki inşa eden bir yapıya büründükçe kurumsal halkla ilişkiler amaçlı kullanımı açısından gerçek değerine ulaşabilecektir. 


\section{KAYNAKÇA}

Adler, Lindsay and Sillars, Rosh (2011) The Linked Photographers' Guide to Online Marketing and Social Media, Cengage Learning, Boston, USA.

Akar, Erkan (2006) Blogla Pazarlama, Tiem Yayıncılık, İstanbul.

Akay, Cenk ve Ültanır, Emel (2010) "Andragojik Temellere Dayalı Kolaylaştııılmış Okuma-Yazma Eğitimi (KOYE) Sürecine Yönelik KOYE Eğiticilerinin Görüşleri”, Mersin Üniversitesi Eğitim Fakültesi Dergisi, 6 (2): 75-88.

Alikılıç, Özlem Aşman (2011) Halkla İlişkiler 2.0 Sosyal Medyada Yeni Paydaşlar, Yeni Teknikler, Efil Yayınevi, Ankara.

Alikılıç, Özlem ve Onat, Ferah (2007) "Bir Halkla İlişkiler Aracı Olarak Kurumsal Bloglar”, Journal of Yaşar University, 8 (2): 899-927.

Atabek, Ümit ve Atabek, Gülseren Şendur (2007) Medya Metinlerini Çözümlemek: İçerik, Göstergebilim ve Söylem Çözümleme Yöntemleri, Siyasal Yayınları, Ankara.

Aziz, Aysel (2015) Sosyal Bilimlerde Araştırma Yöntemleri ve Teknikleri, 10. bs., Nobel Akademik Yayıncılık, Ankara.

Barros, Marcos (2014) "Tools of Legitimacy: The Case of the Petrobras Corporate Blog", Organization Studies, 35 (8): 1211-1230.

Baş, Türker ve Akturan, Ulun (2013) Nitel Araştırma Yöntemleri, 2. bs., Seçkin Yayıncılık, Ankara.

Başkale, Hatice (2016) "Nitel Araştırmalarda Geçerlik, Güvenirlik ve Örneklem Büyüklüğünün Belirlenmesi”, Dokuz Eylül Üniversitesi Hemşirelik Fakültesi Elektronik Dergisi, 9 (1): 23-28.

Bayraktutan, Günseli ve diğ., (2012) “Sosyal Medyada 2011 Genel Seçimleri: Nitel- Nicel Arayüzey İncelemesi”, Selçuk İletișim, 7 (3): 5-29.

Bilgin, Lale (2010) Olumlu İmaj Yaratmak Halkla İlişkiler, Kumsaati Yayınları, İstanbul.

Bozkurt, İzzet (2007) Bütünleşik Pazarlama İletişimi, MediaCat Yayınları, İstanbul.

Brand Finance (2019) "Banking 500, The Annual Report", Erişim Tarihi: 30.11.2019, https://brandfinance.com/images/upload/banking_500_2019_locked.pdf

Cho, Soyoen and Huh, Jisu (2010). "Content Analysis of Corporate Blogs as a Relationship Management Tool", Corporate Communications: An International Journal, 15 (1): 30-48.

Çetintaş, H. Buluthan (2014) "Bir Kurumsal İletişim Stratejisi Olarak Kurumsal Bloglar”, Selçuk İletişim, 8 (3): 92-121.

Dennis, Alan R. et al. (2016) "Mapping the Corporate Blogosphere: Linking Audience, Content, and Management to Blog Visibility", Journal of the Association for Information Systems, 17 (3): 162-193.

Dilmen, Necmi Emel (2007) "Yeni Medya Kavramı Çerçevesinde İnternet Günlükleri-Bloglar ve Gazeteciliğe Yansımaları", Marmara Üniversitesi İletişim Fakültesi Dergisi, 12, 113-123.

Doroschuk, Elena S. and Staroverova, Tatiana, S. (2017) "Blog in the Structure of the Internet-Representations Media: Communicative Aspect", The Turkish Online Journal of Design, Art and Communication TOJDAC, 979-984.

Gawroński, Slawomir and Jakubowski, Roland (2018) "Dispute about Public Relations-Between Social and Marketing Communication", Social Communication, 1, 6-11.

Giarelli, Ellen and Tulman, Lorraine (2003) "Methodological Issues in the Use of Published Cartoons as Data", Qualitative Health Research, 13, 945-956.

Glesne, Corrine and Peshkin, Alan (1992) Becoming Qualitative Researchers an Introduction, Longman Group Ltd, London.

Gunelius, Susan (2011) 30 Minutes Social Media Marketing: Step by Step Techniques toSpread the Word About Your Business Fast and Free, McGraw Hill, New York.

Guth, David W. and Marsh, Charles (2003) Public Relations: A Values-Driven Approach, 2nd Ed., Allyn \& Bacon, Boston.

Harris, Thomas L. (1993) The Marketer's Guide to Public Relations, Wiley, New York.

Holtz, Shel and Demopoulos, Ted (2006). Blogging For Business Everything You Need to Know and Why You Should Care, USA: Dearborn Trade.

Hsu, Chin L. and Lin, Judy C. (2008) “Acceptance of Blog Usage: The Roles of Technology Acceptance, Social Influence and Knowledge Sharing Motivation", Information \& Management, (45): 65-74.

Jarvis, Jeff (2011) E-Sosyal Toplum, Dijital Çağda Sosyal Medyanın İş ve Gündelik Hayata Etkisi, Çağlar Kök (Çev.), MediaCat Yayınları, İstanbul.

Kahraman, Murat (2013) Sosyal Medya 101 2.0 Pazarlamacılar İçin Sosyal Medyaya Giriş, 2. bs., MediaCat Yayınları, İstanbul.

Karaçor, Süleyman (2009) "Halkla İlişkilerde İletişim Aracı Olarak Bloglar”, Niğde Üniversitesi İỉBF Dergisi, 2 (2): 87 99.

Kartal, Aybüke Kardelen ve Algül, And (2019) "Vakıf ve Devlet Üniversitelerinin Kurumsal İmaj Bağlamında Twitter Paylaşımlarının İçerik Analizi”, Yeni Medya Elektronik Dergi (e-JNM), 3 (1): 57-70.

Kılıç, Hicran Ö. (2011). "Kurumsal Blog Sahibi Olmanın Şirketlerin Gelir ve Kârına Etkisi: Fortune 500 Üzerinde Bir Araştırma”, Eskişehir Osmangazi Üniversitesi İiBF Dergisi, 6 (1): 139-162.

Koçak, Sevinç (2017) "Yeni Medya Uygulamalarının Halkla İlişkiler Çalışmalarına Etkisi: Tetrad Kuramı Çerçevesinde Kurumsal Sosyal Sorumluluk Kampanyaları Örneklerinin İncelenmesi”, İletişim Araştırmaları Dergisi, 14 (2): $141-168$ 
Koçyiğit, Murat (2017) Dijital Halkla İlişkiler ve Online Kurumsal İtibar Yönetimi, Eğitim Yayınevi, Konya.

Luo, Nianlong et al. (2018) "Can Non-Work-related Social Media Use Benefit the Company? A Study on Corporate Blogging and Affective Organizational Commitment”, Computers in Human Behavior, (81): 84-92.

Mert, Yener Lütfü (2018) Dijital Halkla İlişkiler Araçlarının Yayıncılık Sektöründe Kullanımına Yönelik Bir Araştırma, Uluslararası Sosyal Araştırmalar Dergisi, 11 (58): 724-737.

Miles, Matthew B. and Huberman, A. Michael (1994) An Expanded Sourcebook: Qualitative Data Analysis, 2nd Ed., SAGE Publications, Inc., Thousand Oaks, CA.

Mucan, Burcu ve Özeltürkay, Eda Yaşa (2014) "Social Media Creates Competitive Advantages: How Turkish Banks Use This Power? A Content Analysis of Turkish Banks through Their Webpages", Procedia-Social and Behavioral Sciences, (148): 137-145.

Neuman, W. Lawrence (2012) Toplumsal Araştırma Yöntemleri: Nicel ve Nitel Yaklaşımlar (Cilt I-II). (Çev. S. Özge), Yayın Odası, İstanbul.

Okmeydan, Selin Bitirim ve Saran, Mine (2018) “Actors of International Public Relations", M. U. Tuncer (Ed.), International Public Relations Practices and Approaches, (p. 29-52). Berlin: Peter Lang.

Olędzki, Jerzy (2017) "Public Relations as a Theatre-style Media Spectacle: Results of a Polish Public Opinion Poll", International Journal of Journalism \& Communication, 4, 1-7.

Özdemir, İlker (2012) "Bankacıllkta Halkla İlişkiler ve Müşteri İlişkileri”, BSAD-Bankacıllk ve Sigortacılık Araştırmaları Dergisi, 1 (3-4): 4-15.

Özdemir, Murat (2010) "Nitel Veri Analizi: Sosyal Bilimlerde Yöntembilim Sorunsalı Üzerine Bir Çalışma”, Osmangazi Üniversitesi Sosyal Bilimler Dergisi, 11 (1): 323-343.

Özel, Aybike P. ve Sert, Nuray Y. (2014). "Dijital Halkla İlişkiler Aracı Olarak Kurumsal Bloglar: Türkiye’nin En Büyük 500 Şirketi Üzerine Bir Araştırma", Global Media Journal TR Edition, 5 (9): 303-321.

Özgüner Kılıç, H. (2011) "Kurumsal Blog Sahibi Olmanın Şirketlerin Gelir ve Karına Etkisi: Fortune 500 Üzerinde Bir Araştırma", Eskişehir Osmangazi Üniversitesi İiBBF Dergisi, 6 (1): 139-162.

Özüdoğru, Şakir (2014) "Bir Web 2.0 Uygulaması Olarak Bloglar: Blogların Dinamikleri ve Blog Alemi”, The Turkish Online Journal of Design, Art and Communication-TOJDAC, 4 (1): 36-50.

Parusheva, Silvia (2019) “Social Media Banking Usage From Banks' Perspective”, International Journal of E-Business Research, 15 (1): 38-54.

Philip, Leena (2017) “Corporate Blogging: The New Age PR Tool”, European Journal of Interdisciplinary Studies, 3 (3): 65-74.

Pitt, Leyland F. et al. (2011) "The Social Media Release as a Corporate Communication Tool for Bloggers", IEEE Transactions on Professional Communication, 54 (2):122-132.

Porter, Lance et al. (2009) "The Blogosphere and Public Relations Investigating Practitioners' Roles and Blog Use", Journal of Communication Management, 13 (3): 250-267.

Pradas, Santiago Iglesias, et al. (2017) "Acceptance of Corporate Blogs for Collaboration and Knowledge Sharing", Information Systems Management, 34 (3): 220-237.

Ramadanty, Sary and Martinus, Handy (2018) "The Role of Bloggers in Public Relations Activities in Indonesia”, Social Sciences \& Humanities, (26): 263-274.

Roberts, Paula and Priest, Helena (2006) "Reliability and Validity in Research", Nursing Standard, 20, 41-45.

Seitel, Fraiser P. (2016) Halkla İlişkiler Uygulaması, Seda Mengü (Çev.), 12. bs., Nobel Yayınları, Ankara.

Severin, J. Werner and Tankard, W. James (1994) İletişim Kuramları: Kökenleri, Yöntemleri ve Kitle İletişim Araçlarında Kullanımları, Kibele Sanat Merkezi, Eskişehir.

Sevinç, Salih Seçkin (2012) Pazarlama İletişiminde Sosyal Medya, Optimist Yayın ve Dağıtım, İstanbul.

Silverman, David (2005) Doing Qualitative Research: A Practical Handbook. Sage Pub., London.

Suziki, Lisa A. et al. (2007) "The Pond You Fish in Determines the Fish You Catch: Exploring Strategies for Qualitative Data Collection", The Counseling Psychology, 35, 295-328.

Thomas, Lorrie (2011) Online Marketing, McGraw Hill, New York.

Wilcox, Dennis L. et al. (1998) Public Relations. Strategies and Tactics, 5th Ed., New York: Longman.

Wright, Donald K. and Hinson, Michelle D. (2008) "How Blogs and Social Media are Changing Public Relations and the Way it is Practiced", Public Relations Journal, 2 (2): 1-21.

Wright, Jeremy (2005) Blog Marketing, MacGraw Hill Companies, USA.

Xifra, Jordi and Huertas, Assumpcio (2008) "Blogging PR: An Exploratory Analysis of Public Relations Weblogs" Public Relations Review, (34): 269-275.

Yang, Sung-Ung and Lim, Joon Soo (2009) "The Effects of Blog-Mediated Public Relations (BMPR) on Relational Trust", Journal of Public Relations Research, 21 (3): 341-359.

Yengin, Deniz (2017) İletişim Çalışmalarında Araştırma Yöntemleri ve Uygulamaları, Der Yayınları, İstanbul.

Yıldırım, Ali ve Şimşek, Hasan (2013) Sosyal Bilimlerde Nitel Araştırma Yöntemleri, 9. bs., Seçkin Yayıncılık, Ankara. Yıldız, Nuran (2010) "Halkla İlişkilerde Kavramlar, Sınıllar, Sorunlar", Selçuk İletişim Dergisi, 6 (2): 24-32.

Zyl, Anria S. (2009) “The Impact of Social Networking 2.0 on Organizations”, The Electronik Library, 27 (6): 906-918. 